Running head: BEYOND GPA

Beyond Grade Point Average of University Students: Theoretical Foundations for the Achievement as a Process Approach with an Empirical Illustration

Patrick Gaudreau

University of Ottawa

This pre-print is currently under review and will likely change during the review process. This is not the copy of record and may not exactly replicate the final authoritative published version.

Version 1 October $2^{\text {nd }} 2018$

\title{
Acknowledgement
}

This research was facilitated by SSHRC research grants (\#410-211-1774; \#435-215-0649) and teaching releases from the Faculty of Social Sciences. I thank Jean-Luc Daoust and Pierre Mercier at Research and Institutional Planning for access to the achievement data. I also thank Jérémie Verner-Filion and Safi Sayeed for their data preparation and preliminary analyses. I also thank everyone in the Laboratory for research on Achievement, Motivation and Regulation of Action (Ben Schellenberg, Katie Gunnell, Alexandre Gareau, Véronique Franche, Kristina Kljajic, Mélodie Chamandy, Laurence Boileau-Perreault, Amanda Thompson, Natasha Carraro, and Adam Kingsbury) whose daily conservations and ongoing research endeavors have stimulated the emergence of the research perspectives presented in this manuscript. 


\begin{abstract}
Psychological research in tertiary education typically follows the achievement as an outcome approach in which the focus is placed on inter-individual differences in the achievement level of students (e.g., semester GPA, cumulative GPA). In this article, the achievement as a process approach is proposed to reconceptualise academic achievement as a developmental story with far reaching consequences. Three principles are articulated to posit that the trajectory of academic achievement differ across students (principle \#1) and that such inter-individual differences are consequential (principle \#2) and far reaching (principle \#3) predictors of longterm success of students (e.g., retention, timely graduation). An empirical illustration is presented and results of growth curve analyses indicate that (a) an achievement shock during the first year, (b) a bounce back effect during the second year, and (c) continuous improvement during the junior and senior years improves our capacity to predict long-term success of university students and outperforms the typical predictors used by universities. This new approach has far reaching consequences for the management, services, policies, and research agenda of people working to promote the success of students. Six broad implications are delineated to steer research and practices in novel, needed, and promising directions across tertiary education and beyond.
\end{abstract}

Keyword: achievement, performance, tertiary education, learning, retention, graduation, perseverance, success 


\section{Beyond Grade Point Average of University Students: Theoretical foundations for the Achievement as a Process Approach with an Empirical Illustration}

Universities invest considerable resources to offer an optimal learning environment to their students. Despite such efforts, tertiary education institutions face many challenges. Tuitions increase more steeply than what the middle-class students and their parents can realistically afford. Skeptics voice their doubts about the proclaimed advantages of tertiary education. Policy makers, employers, and students ask difficult questions about the preparedness of university graduates for real-life challenges. We live in a time of economic scarcity and universities, once again, face the challenging task of justifying their socio-economical plus-value (e.g., Evans, Kandiko Howson, \& Forsythe, 2018). Given all of the above, educational researchers must pay even closer attention to understand and promote the academic achievement and success of the millions of undergraduates studying in our campuses each and every year.

Psychological sciences is strategically positioned to foster a deeper understanding of the many social, organizational, motivational, emotional, and cognitive factors contributing to the academic success of students in tertiary education. In this article, my goal is to delineate the theoretical and empirical foundations for a way of conceptualizing academic achievement beyond the typical focus on Grade Point Average (GPA). More precisely, I will advance that consequential information can be uncovered by conceptualizing academic achievement as a developmental process. I will delineate three key principles and examine how they come into play at critical periods for students enrolled in four-year programs. What we know about the academic achievement of $1^{\text {st }}$ year students, sophomores, juniors and seniors will be overviewed. Accompanied with an empirical illustration, I will showcase how the trajectory of achievement rather than the level of achievement itself - can improve our capacity to predict, understand, and 
eventually intervene to promote both year-to-year retention of students and their timely graduation - two critical indicators defining the long-term success of both students and tertiary education institutions. Finally, I will discuss the broader implications of the achievement as a process approach in tertiary education and beyond.

\section{The Traditional Definition of Academic Achievement: Achievement as an Outcome}

Promoting the success of students is the prime mission of tertiary education. Two sustained and ongoing streams of psychology research significantly contribute to this mission (for an extensive review, see Hattie, 2009). On the one hand, proponents of a correlational approach devise cross-sectional and longitudinal studies to identify and compare the psychosocial correlates of academic achievement (e.g., Fong et al., 2016; Richardson, Abraham, \& Bond, 2012; Schneider \& Preckel, 2017). On the other hand, tenants of an experimental approach create lab and field experiments in which they manipulate and intervene on psychosocial factors to cause changes in academic achievement (e.g., Harackiewicz \& Priniski, 2018; Lazowski \& Hulleman, 2016; Robbins, Oh, Le, \& Button, 2009). Both streams of research are needed for theory development and refinement and to help universities in creating an optimal learning environment.

Defining, studying, and intervening on academic achievement is a complex and multifaceted endeavor. Academic achievement is a multilevel construct with specific instances of performance nested into growingly larger units of achievement (see Dalal, Bhave, \& Fiset, 2014 for similar ideas in the work domain). The many assignments of a course (i.e., task performance) are aggregated to represent the level of achieved performance in that course (i.e., class grade). Students take multiple courses during each semester. Hence, their grades in individual courses are averaged and weighted by the number of credits earned during a semester (i.e., semester 
GPA), which are then aggregated across all semesters already taken by a student to create a cumulative GPA. Academic achievement should be conceived and investigated at different levels of analysis.

Most psychology research has remained rather vague in their definition of academic achievement. The umbrella term "grade point average" or GPA is typically used to denote any types of objective academic achievement retrieved from the office of the registrar. In their metaanalysis of the correlational literature, Richardson and her colleagues (2012, see p. 354) clearly defined the GPA as the "means of marks from weighted courses contributing to assessment of the final degree". Yet, their meta-analysis reverted back to an umbrella definition that included “students' overall degree marks, quarter, semester, course, or test marks” (see p. 363). Similarly, Robbins et al. (2009) included together GPA, cumulative GPA, semester GPA, and grades in individual courses in their meta-analysis of the experimental literature. In all fairness, metaanalysists are often forced to bundle because their primary sources rarely define the precise unit of analysis under investigation. When the unit of analysis is clearly specified (e.g., Credé \& Kuncel, 2008), the effect size of psychosocial factors appears to be fairly comparable across units of analysis (e.g., grades in individual classes, semester GPA, cumulative GPA). Yet, the effect of psychosocial interventions with university students appear to yield stronger effects on grades in individual classes than on cumulative GPA (Robbins et al., 2009). The unit of analysis does matter.

The correlational and experimental research streams respectively aim at identifying and intervening on the precursors of academic achievement. Failure to clearly specify the unit of analysis can easily lead to biased interpretation, tautological reasoning, and model mispecifications. For example, several social/educational psychology theories (e.g., Bandura, 
2001; Lazarus \& Folkman, 1984; Marsh \& Craven, 2006) postulate a bidirectional relationship between non-cognitive factors (e.g., self-efficacy, academic self-concept) and academic achievement. Imagine that a researcher correlates self-efficacy with cumulative GPA in a sample of $2^{\text {nd }}$ year students. Their cumulative GPA will conflate information about both their past and subsequent performances. As a result, the correlation between self-efficacy and cumulative GPA will muddle the effect of self-efficacy on future academic achievement and the effect of past academic achievement on self-efficacy. Despite the intricate presence of conflated effects, several researchers and their readers will inadvertently conclude that self-efficacy influences achievement and is therefore a prime candidate for intervention to promote academic success. Greater precision in our operationalization of academic achievement is required to separate cause and effect to ensure the proper specification of both theories and intervention programs.

Research from both the correlational and experimental traditions typically follows what I will hereafter call the achievement as an outcome approach. In this approach, indicators of achievement (e.g., grade in one course, semester GPA, cumulative GPA) are conceptualized as time-invariant and static dependent variables. This conceptualization, albeit pragmatic and efficient, solely focuses on inter-individual differences in the achievement level of university students. Some students are more academically successful than others and this analytical paradigm aims solely at explaining the between-person variance in achievement. Members of the tertiary education community (e.g., teachers, service providers, administrators) rarely question the utility of this measurement approach. Why would they? On the one hand, some students are undeniably more academically successful than others (e.g., Krapohl et al., 2014; R. C. Martin, 2015). Individual differences in academic achievement are both real and consequential. On the other hand, members of the tertiary education community also use a similar premise to appraise 
university students. Recruitment, grading, scholarship, probation, and admission to graduate school policies are strongly determined by the rank-ordering of students' academic achievement. Inter-individual differences are the yardstick upon which students, and the institutions hosting the students (e.g., retention, graduation rates), are assessed and held accountable.

\section{Beyond GPA: The Achievement as a Process Approach}

Despite both their usefulness and face validity, aggregated achievement outcomes (e.g., GPA) provide limited insight about how the achievement of students develops over time. The first panel of Figure 1 shows the case of two students graduating with the same GPA of B. The first student started off strong in his/her $1^{\text {st }}$ year and he/she kept a comparable level of achievement throughout. In contrast, the second student experienced numerous setbacks in his/her $1^{\text {st }}$ year but steadily improved up to a point where he/she was a straight "A" student in his/her $3^{\text {rd }}$ and $4^{\text {th }}$ year. Using the typical achievement as outcome approach, both students would be categorized as "average students" despite their very distinct development of achievement.

The same observation generalizes at other levels of analysis. The second panel of Figure 1 shows the disaggregated achievement of two students finishing their $1^{\text {st }}$ semester with a semester GPA of B. The first student only had slight fluctuations in his/her grades across five courses. The second student showed flashes of brilliance with a few A and instances of academic difficulties with a few disappointing results. Both students would be categorized as "average students" despite the different within-person fluctuations of their grades in their courses.

In the current research, I articulate the foundations of a novel approach to unravel the uncaptured richness underlying academic achievement. Hereafter, I will refer to this approach as the achievement as a process approach. This approach acknowledges and does not dismiss the 
existence and the consequential nature of between-person differences in academic achievement.

Yet, it switches the focus to within-person fluctuations and developmental changes in achievement (e.g., Beal, Weiss, Barros, \& MacDermid, 2005; Dalal et al., 2014; Kljajic \& Gaudreau, 2018; Roe, 2014) to offer a new platform to help researchers and practitioners uncovering novel information beyond the GPA of university students.

The achievement as a process approach conceives academic achievement as both an episodic and a developmental process. On the one hand, the approach focuses on the episodic and ecological context in which specific instances of achievement occurs. For example, the achievement of students in the context of a course is potentially better understood through the psychosocial experience of the students in that particular course (e.g., Kljajic \& Gaudreau, 2018). Similarly, the achievement of students during their $1^{\text {st }}$ semester on campus is potentially better understood through their psychological experience while transitioning from high school to the university. On the other hand, the achievement as a process approach is developmental because it focuses on how the story of achievement develops over time for university students. I assume that academic achievement differently unfolds for different students (principle \#1). Plus, I advance that such inter-individual differences in the developmental course of achievement are consequential (principle \#2). So far, the generalized focus on between-person differences in GPA has prevented our research community from paying closer attention to the types of within-person differences portrayed in the case of our two prototypical students in Figure 1. In fact, classic statistical analyses (e.g., between-group comparison) and our cumulative scores of achievement (e.g., GPA) have treated within-person fluctuations as mere measurement error or an artefactual methodological nuisance (e.g., Beal et al., 2005; Dalal et al., 2014). In contrast, the achievement as a process approach offers a roadmap to look beyond GPA by examining academic 
achievement at multiple levels of analysis. Inter-individual differences in the developmental course of academic achievement should explain unique variance in academic success (e.g., $2^{\text {nd }}$ year retention, graduation rates) over and above inter-individual differences in the level or point estimate of achievement. For example, the change in academic achievement from high school to the $1^{\text {st }}$ semester of tertiary education should predict the likelihood of returning after the first year (e.g., $2^{\text {nd }}$ year retention) over and above admission GPA and the $1^{\text {st }}$ semester GPA. Finally, I advance that such effects should be far reaching, extend beyond the $1^{\text {st }}$ year of tertiary education, and predict indicators of long-term academic success such as retention beyond the $2^{\text {nd }}$ year and timely graduation (principle \#3).

In the following sections, I will focus on the developmental course of academic achievement (a) during the transition from high school to the $1^{\text {st }}$ year at the university, (b) during the $2^{\text {nd }}$ year, and (c) beyond the $2^{\text {st }}$ year of tertiary education. Each of the three sections will start with an overview of the literature to summarize each of these important developmental periods. Then, I will showcase the findings from a four-year longitudinal study conducted on a large sample of university students with the goal of illustrating the three principles of the achievement as a process approach. Description of the sample and more technical information about the statistical analyses are reported in a supplementary file.

\section{The First-Year at the University}

\section{Academic Achievement of $1^{\text {st }}$ Year Students}

The transition from high school to university is generally described as a demanding and stressful developmental task (e.g., Bruffaerts et al., 2018; Hurst, Baranik, \& Daniel, 2013; Lane, 2018). In fact, researchers, practitioners, and administrators commonly assume that $1^{\text {st }}$ year 
university students will experience an "academic shock" in which their academic achievement will severely drop compared to high school (Finnie \& Martinnello, 2010). As a result, the correlational research stream produces a countless number of studies each year on the psychological experience of $1^{\text {st }}$ university students (Richardson et al., 2012; van der Zanden, Denessen, Cillessen, \& Meijer, 2018). Over the last three decades, a specific line of investigations has focused on the measurement of students' adaptation to tertiary education (Baker \& Siryk, 1984; Credé \& Niehorster, 2012). Orientation programs, workshops, mentoring, and counseling specifically designed to help $1^{\text {st }}$ students are manifolds and widespread (e.g., Lane, 2018). Systematic and rather costly interventions such as the First Year Seminars are commonly offered and sometimes universally implemented on campuses across North America (Permzadian \& Credé, 2015). A peer-reviewed scientific outlet - the Journal of the First-Year Experience and Students in Transition - is even dedicated to the experiences of transitioning to tertiary education. All that to say, frosh students are attracting a big part of the lion's share of correlational and experimental research on academic achievement in tertiary education.

Limited empirical effort has been allocated to investigate the extent to which the grades of an average student normatively decrease from high school to the $1^{\text {st }}$ year of university. Three set of valid and informative empirical findings could help explain why the mean-level drop in academic achievement remains under-studied. First, meta-analyses provided robust evidence for the moderate-to-strong rank-order stability of grades across time. In their meta-analytical review of 46 studies with 34,724 students, Richardson and her colleagues (2012) found a test-retest correlation of .40 between high school GPA and university GPA. Based on the data of 189,612 students across 50 institutions, Westrick and his colleagues (2015) reported a correlation of .47 between self-reported high school GPA and $1^{\text {st }}$ year GPA. Second, many solid research programs 
have shown the incremental validity of high school GPA to predict downstream academic achievement of university students. In their meta-analytical multiple regression, Robbins and his colleagues (2004) revealed that high school GPA remains a significant predictor of university GPA after controlling for socio-economic status, college admission tests, achievement motivation, academic goals, and academic self-efficacy. Given its strong incremental validity, the tertiary education community still rely on high school GPA as a golden criterion to administer their recruitment, admission, and scholarship policies.

The rank-order stability and incremental validity of academic achievement, in isolation or taken together, should not be taken as evidence against the need to investigate the mean-level normative decreases in grades. Test-retest correlations and regression paths can only answer questions about the stability in the rank-ordering of students' achievement. A moderate-to-strong correlation only indicates that most individuals are keeping approximately the same relative positioning in the distribution of grades over time. In other words, most of the top-ranked high school students remain amongst the top-ranked university students while most of the students with the lowest admission GPA remain on the left tail of the distribution once at the university. Such evidence, however, offers little indication about the extent to which the grades of the students numerically and normatively decrease across measurement points. Rank-order stability often combines with mean-level change. Although people can keep the same relative positioning in the population over time, they nonetheless tend to normatively become better or worse with the passage of time (e.g., Caspi, Roberts, \& Shiner, 2005; McAdams \& Olson, 2010).

Results from a representative sample of 5,200 Canadian university students have shown that a typical student should expect to experience a $9.7 \%$ decrease in their grades from their last year of high school compared to their $1^{\text {st }}$ year GPA at the university (Finnie \& Martinnello, 
2010). A majority of students in Canadian universities are admitted with high school GPA above $80 \%$. Based on these findings, a student admitted with $85 \%$ should expect to finish his/her $1^{\text {st }}$ year with a cumulative GPA of B+ and would be right on the bubble or below the required threshold to maintain his/her scholarship. Considering that tuitions have significantly increased (and will likely continue to do so), the "academic shock" of the $1^{\text {st }}$ year holds consequential socioeconomic outcomes for students and families.

Normative mean-level change in academic achievement does matter and deserves more theoretical and empirical attention. In our work as teachers and service providers, we rarely come across students saying "I was at the $85^{\text {th }}$ percentile in high school and I am still at the $85^{\text {th }}$ percentile this year; therefore, I feel like a good university student even if my grades have decreased". Students are mostly unaware of their exact relative positioning in the overall distribution of grades. In their respective high school, a majority of university students were on top of the pot (e.g., the big fishes of their pound) but they now compete against other big fishes with comparable ability and skills (Marsh et al., 2008). Despite not being aware and fully informed of such details, they are definitively aware and discouraged when their grades plunges one or two marks bellow their high school grades (e.g., from A to B+). Such changes, even in the unperceivable presence of rank-order stability, are perceptible and disheartening to students.

As teachers, service providers, or administrators you may have come across some students who walk through their $1^{\text {st }}$ year as if it was "a walk in a park". There is no doubt that inter-individual differences exist in the developmental course of academic achievement during transition periods (e.g., Suarez-Orozco et al., 2010; Yeager \& Dweck, 2012). In the achievement as a process approach, I advance that these inter-individual differences in development are not only interesting but pivotal. Although the academic achievement is likely to decrease on average, 
not all students will decrease to the same extent. The good news may be that not everyone should experience the same amount of "academic shock" once they enter university. If so, we need this information to readily inform members of the tertiary education community that the typical, astonishing, and demoralizing "academic shock" does not generalize to all students on campus. Students entering tertiary education with excellent grades may be more (i.e., regression to the mean) or less (i.e., Matthew effect) susceptible to experience a strong academic shock. Success breeds success. We also need to investigate if inter-individual differences in the developmental course of academic achievement influence year-to-year likelihood of returning to school (i.e., retention) and their likelihood of graduating in a timely manner. Paying a much closer attention to the developmental story of achievement of each student is required to promote the short-term and long-term academic success of students in tertiary education.

\section{$2^{\text {nd }}$ Year Retention: Will They Be back Next Fall?}

Returning back the following fall (i.e., retention) and graduating in a timely manner (i.e., after four years) are the epitome of academic success in tertiary education (e.g., Barbera, Berkshire, Boronat, \& Kennedy, 2018). Education is a long-term investment for the students and abandoning after the $1^{\text {st }}$ year is a costly decision. On the one hand, tuitions and peripheral fees spent during the $1^{\text {st }}$ year are simply lost forever. As such, the student and his/her family will never experience the anticipated socioeconomic returns of their investment. Let alone initial costs, research has clearly outlined the many long-term economic, health, and social benefits associated with graduating with a tertiary education diploma (e.g., Mackenbach et al., 2015; Smith, Anderson, Salinas, Horvatek, \& Baker, 2015). On the other hand, the institutions hosting the students are incurring an important socioeconomic lost when students decide to withdraw from their programs. Many institutions are potentially matriculating more $1^{\text {st }}$ year students 
knowing that they will lose many of them along the way. Important resources (e.g., time, money, human resources, and effort) are allocated to support large cohort of $1^{\text {st }}$ year students with the hope of maximizing their academic achievement, learning, and likelihood of retention and graduation. Once students leave, an institution needs to reinvest additional human resources and money in recruitment, admission procedures, and matriculation of the new $1^{\text {st }}$ year students filling out the vacant spot. Institutional reputation, both national and international ranking of universities, and governmental funding are increasingly contingent and compromised when too many students decide to leave an institution along the way.

$2^{\text {nd }}$ year retention is a major concern for students, parents, administrators, and governmental agencies with a national average of $19 \%$ of American students not pursuing their tertiary education beyond the $1^{\text {st }}$ year in four-year institutions (McFarland et al., 2018). Studies have found that both high school GPA and $1^{\text {st }}$ year GPA significantly predict the likelihood of $2^{\text {nd }}$ year retention, with meta-analytical estimates of .17 and .38 , respectively (Westrick, Le, Robbins, Radunzel, \& Schmidt, 2015). Although retention rates substantially differ across institutions, these meta-analytical estimates are largely invariant across universities with less and more selective admission policies. Furthermore, the bivariate meta-analytical correlation between cumulative GPA and retention $(r=.44)$ has been shown to remain statistically significant $(r=.38)$ in meta-analytical path analyses (Robbins et al., 2009) controlling for emotional (e.g., anxiety, stress, self-efficacy), motivational (e.g., study skills, goals, achievement motivation), and social factors (e.g., seeking social support, social involvement).

In the achievement as a process approach, I advance that point estimates of academic achievement (e.g., SGPA, $1^{\text {st }}$ year GPA) only reveal a partial glimpse of the predictive value of academic achievement to predict $2^{\text {nd }}$ year retention. Yet, these point estimates are currently the 
golden criterion entered in the predictive/analytic models used by service providers to target and reach out at-risk $1^{\text {st }}$ year students (e.g., Attewell, Heil, \& Reisel, 2012; Westrick et al., 2015). Based on the assertions that inter-individual differences exist in the developmental trajectory of achievement (principle \#1) and that such differences are consequential (principle \#2), I advance that more positive changes from high school GPA to $1^{\text {st }}$ semester GPA and from $1^{\text {st }}$ to $2^{\text {nd }}$ semester GPA should increase the likelihood of $2^{\text {nd }}$ year retention over and above point estimates of achievement (i.e., high school GPA, $1^{\text {st }}$ SGPA). The next section summarizes findings from a longitudinal study in which these two assertions were put under empirical scrutiny.

\section{Empirical Illustration}

Overview. I examined the admission GPA, $1^{\text {st }}$ semester GPA, and $2^{\text {nd }}$ semester GPA of 4212 students enrolled in a Canadian university to estimate their trajectory of academic achievement during the transition from high school to the $1^{\text {st }}$ year at the university. Estimated sample mean and standard deviations are reported in Table S1 (see supplementary file). Meanlevel analyses revealed a strong decline in grades from high school to the $1^{\text {st }}$ semester, $d=$ $0.997,95 \% \mathrm{CI}=[-1.061,-0.933]$, but a small decline from the $1^{\text {st }}$ to the $2^{\text {nd }}$ semester $(d=-0.109$, $95 \% \mathrm{CI}=[-0.169,-0.048]$. Rank-order stability was .622 from high school to the $1^{\text {st }}$ semester and .816 from the $1^{\text {st }}$ to the $2^{\text {nd }}$ semester. The rank-order stability coefficients were moderate-tostrong. Consistent with past research, the relative positioning of students in the distribution of grades was quite stable across time. However, the average grades of students strongly decreased during the transition from high school to university. Academic achievement manifested both relative rank-order stability and mean-level normative change.

Trajectory of achievement during the $1^{\text {st }}$ year. We performed a piecewise growth model (e.g., Chou, Yang, Pentz, \& Hser, 2004; Curran, Obeidat, \& Losardo, 2010) to isolate and 
directly test the statistical significance of the change from high school to the $1^{\text {st }}$ semester (slope \#1) and from the $1^{\text {st }}$ semester to the $2^{\text {nd }}$ semester (slope \#2). A detailed explanation of model specification can be found in the online supplementary file.

Parameter estimates of this model are reported in Table 1 and the predicted values are shown in the first panel of Figure 2. The grades of students significantly decreased from high school to the $1^{\text {st }}$ semester (slope \#1). They also significantly decreased from the $1^{\text {st }}$ to the $2^{\text {nd }}$ semester, but to a lesser extent (slope \#2). The intercept positively and significantly correlated with slope \#1, thus showing that students who entered university with higher admission GPA experienced more positive change (i.e., a smaller decline) during their $1^{\text {st }}$ semester (i.e., Matthew effect). Consistent with principle \#1 of our achievement as a process approach, the slopes differed significantly across participants. The achievement trajectory was qualified by a significant amount of inter-individual differences displayed in the second panel of the Figure 2.

Predicting the $2^{\text {nd }}$ year retention. We added a distal binary outcome $(0=$ not returning in fall of $2^{\text {nd }}$ year; $1=$ returning in fall of $2^{\text {nd }}$ year) to our piecewise growth model to examine if inter-individual differences in change in academic achievement from high school to the $1^{\text {st }}$ semester (slope \#1) and from the $1^{\text {st }}$ to the $2^{\text {nd }}$ semester (slope \#2) significantly predict $2^{\text {nd }}$ year retention (for a similar approach, see Kim, Petscher, Schatschneider, \& Foorman, 2010; Tolar, Barth, Fletcher, Francis, \& Vaughn, 2014). We tested two separate models to investigate the effects of slope \#1 and slope \#2 while controlling for inter-individual difference in high school GPA (model 1) and $1^{\text {st }}$ semester GPA (model 2), respectively (e.g., Muthén \& Muthén, 2000). A detailed explanation of model specification can be found in the online supplementary file.

As shown in Figure 3, the results of both models revealed that inter-individual differences in the change of academic achievement from high school to the $1^{\text {st }}$ semester (slope \#1) and from 
the $1^{\text {st }}$ to the $2^{\text {nd }}$ semester (slope \#2) significantly predicted $2^{\text {nd }}$ year retention after controlling for point estimate of achievement in high school GPA (model 1) and $1^{\text {st }}$ semester SGPA (model 2). Both models explained $37 \%$ of variance in $2^{\text {nd }}$ year retention. The effect size of point estimate of achievement (i.e., intercept) in high school and $1^{\text {st }}$ semester to predict $2^{\text {nd }}$ year retention was small (Model 1 and 2: OR $=1.218$, Cohen's $d=0.109$ ). In contrast, the effect size of slope \#1 (Model 1: OR $=2.693$, Cohen's $d=0.546$; Model 2: OR $=2.210$, Cohen's $d=0.437$ ) and slope \#2 (Model 1: OR $=2.725$, Cohen's $d=0.553$; Model 2: OR $=2.752$, Cohen's $d=0.558$ ) to predict $2^{\text {nd }}$ year retention were quite substantial in both models.

Of particular interest, the effects of slope \#1 and slope \#2 were both significantly stronger than the effect size of admission GPA (Model 1, diff slope1/intercept $=0.794$, S.E. $=0.175, p<.001$; $\operatorname{diff}_{\text {slope } 2 / \text { intercept }}=0.812$, S.E. $\left.=0.239, p=.002\right)$ and $1^{\text {st }}$ semester GPA $($ Model 2, diff slope $1 /$ intercept $=$ 0.596$, S.E. $=0.261, p=.022 ;$ diff slope $2 /$ intercept $=0.815$, S.E. $=0.259, p=.002)$. The effect size of

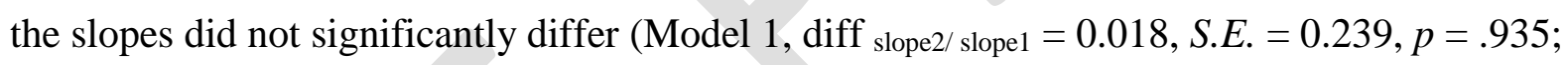
Model 2, diff $_{\text {slope2/slope } 1}=0.219$, S.E. $\left.=0.258, p=.395\right)$; they were equally important to predict retention. Overall, change in academic achievement during the $1^{\text {st }}$ and $2^{\text {nd }}$ semester were significant and stronger predictors of $2^{\text {nd }}$ year retention than admission and $1^{\text {st }}$ semester GPA.

Key implications. On average, students experience an "academic shock" during $1^{\text {st }}$ year. They enter with a high school GPA of A-/B+ and they finish their $1^{\text {st }}$ and $2^{\text {nd }}$ semesters with SGPA of B/C+. Changes from high school to the $1^{\text {st }}$ semester and from the $1^{\text {st }}$ to the $2^{\text {nd }}$ semester are statistically significant with strong and small effect size, respectively. Students have not reached the rock bottom after their $1^{\text {st }}$ semester as their grades still decrease during the winteralbeit to a smaller degree. 
Consistent with principle \#1 of the achievement as a process approach, the amount of academic shock varies across students. The trajectory of an average student (see first panel of Figure 2) is qualified by a significant amount of inter-individual differences (see second panel of Figure 2). Part of this heterogeneity appears attributable to past achievement because the grades of students with higher admission GPA decline to a lesser extent during their $1^{\text {st }}$ year. Students with an admission GPA of A+ (i.e., 10) should expect their grades to drop by only 1.24 points during their $1^{\text {st }}$ year - a significant attenuation compared to the average decline of 2.53 points for those with an average admission GPA (i.e., 7.57). These findings are consistent with a Matthew effect and with the idea that success breeds success (e.g., Marsh \& Craven, 2006) and creates academic momentum (e.g., Martin, Wilson, Liem, \& Ginns, 2013).

Consistent with principle \#2, the trajectory of academic achievement significantly predicts $2^{\text {nd }}$ year retention, over and above the point estimates of academic achievement. The probability of $2^{\text {nd }}$ year retention is higher for the students who experience a small decrease in academic achievement from high school to the $1^{\text {st }}$ semester and from the $1^{\text {st }}$ to the $2^{\text {nd }}$ semester. The effect sizes associated with the developmental story of achievement are consequential and stronger than the effect size associated with the point estimates of achievement (i.e., admission GPA and $1^{\text {st }}$ semester GPA). The developmental story of achievement not only predicts $2^{\text {nd }}$ year retention, but it significantly outperforms the typical predictors. This new piece of information, uncovered by the achievement as a process approach, should be seriously considered by universities to obtain accrued precision to identify students with greater risk of not returning for the $2^{\text {nd }}$ year. Conceiving achievement as a process is needed to complement the typical achievement as an outcome approach currently in use in psychological research and intervention as well as in educational administration, services, and policies. 


\section{The $2^{\text {nd }}$ Year at the University}

\section{Bouncing Back or Slumping during the Sophomore Year?}

Despite the vast resources invested to track and intervene on the experience of $1^{\text {st }}$ year students, the sophomore year appears just as pivotal to promote the long-term academic success of university students (Schaller, 2010). The $1^{\text {st }}$ year is probably a "rite de passage" - a developmental transition that everyone has to go through to learn their way around the unwritten rules of tertiary education. Let alone the multifarious socioeconomic implications, abandoning after the $1^{\text {st }}$ year is first and foremost a missed opportunity for subsequent psychosocial and intellectual growth. Despite the limited attention paid to achievement and retention of sophomores, there are just as many students abandoning after their $2^{\text {nd }}$ year; retention is a not a problem limited to the $1^{\text {st }}$ year students (e.g., Allen, Robbins, Casillas, \& Oh, 2008; Schaller, 2010). Moreover, many important skills and life lessons still have to be learned during the $2^{\text {nd }}$ year (Graunke \& Woosley, 2005; Schaller, 2010). For example, students are introduced to knowledge and skills more specialized toward their major. The capacity of $2^{\text {nd }}$ year students to acquire the specialized knowledge, language, and skills of their respective discipline is important for continuous progress along their chosen academic path. The $2^{\text {nd }}$ year also acts as a transition point during which students explore their interests and make important academic (Galotti, 1999) and career decisions (Guay, Ratelle, Senecal, Larose, \& Deschenes, 2006). The sophomore year is a pivotal but under researched developmental period (e.g., Sterling, 2018; Tobolowsky, 2008).

Despite the aforementioned challenges, a majority of sophomores should start bouncing back in the $2^{\text {nd }}$ year. In fact, findings from the National Sophomore Survey indicate that $63 \%$ of students feel that their $2^{\text {nd }}$ year has been better or much better than their $1^{\text {st }}$ year (e.g., Schreiner, 2010). Their academic achievement may not fully return to the level it was in high school due to 
the competitive nature of tertiary education. Yet, a majority of students should start experiencing a bounce back that will potentially curb and eliminate the negative effect of the unpleasant academic shock of the $1^{\text {st }}$ year. Good things may come for some of those who stay.

Evidence of a bounce back effect remains scarce in the literature for at least two reasons.

First, researchers have less frequently delved into the specific psychological experience of the $2^{\text {nd }}$ year students (e.g., Nora, Barlow, \& Crisp, 2005; Sterling, 2018). As eloquently summarized by Schaller (2010, p. 16), "although the literature on the first-year experience is extensive, major gaps exist with regard to persistence beyond the first year". The sophomore year has even been described as the "forgotten year" (Tobolowsky, 2008). Second, most psychology research in tertiary education (including our own) has remained vague in defining and characterizing samples of participants. The umbrella term "university students" is typically used to describe samples in which only $1^{\text {st }}$ year students or a mixture of $1^{\text {st }}, 2^{\text {nd }}, 3^{\text {rd }}$, and $4^{\text {th }}$ year students are under investigation. Even meta-analysists are often forced to merge all students together (e.g., Richardson et al., 2012), considering that their primary sources rarely split up and compare effect sizes across levels of tertiary education. Although recruiting students across the frosh to the senior years is informative to brush a general portrait of the students' experience, these studies leave important gaps in our specific understanding of the $2^{\text {nd }}$ year experience.

Research on the grades of $2^{\text {nd }}$ year students has mostly focused on their rank-order stability. Results generally indicate that year-to-year achievement display moderate temporal stability. In a study of 904 Australian university students, Martin and his colleague (2013) reported that the paths between the fall and winter semester GPA $\left(1^{\text {st }}\right.$ year, $\beta=.35 ; 2^{\text {nd }}$ year, $\beta=$ .34) were significantly stronger than the path from the winter semester of the $1^{\text {st }}$ year and the fall semester of the $2^{\text {nd }}$ year $(\beta=.18)$. This finding is interesting because the transition from the $1^{\text {st }}$ to 
the $2^{\text {nd }}$ year appears to be a tipping point with a significant amount of inter-individual differences in the developmental story of achievement.

A recent study of Cochran and O'Flaherty (2017) followed the mean-level semester GPA of 398 students during the four-year of their teacher preparation programme. Results of growth curve modeling provided evidence for a model qualified by both linear and quadratic changes. Using the parameter estimates reported by these authors, I created a figure of the predicted values to facilitate interpretation. As shown in Figure S1 (see supplementary file), the semester GPA of students initially decreased during the first two years before increasing in the middle of the $3^{\text {rd }}$ year. Consistent with principle \#1 of the achievement as a process approach, variance of the growth terms indicated significant inter-individual differences in the trajectory of achievement. Plus, a significant but small bounce back effect was observed during the $3^{\text {rd }}$ rather than the $2^{\text {nd }}$ year. These results should be interpreted with caution for at least two reasons. First, teachers' education follows a programmatic curriculum in which students are teaching in real classrooms in their $3^{\text {rd }}$ and $4^{\text {th }}$ years; this learning experience differs from most lecture-based undergraduate programs. Second, no provision was made for retention versus dropouts after the $1^{\text {st }}, 2^{\text {nd }}$, and $3^{\text {rd }}$ year. Including the students who dropped out of school in the four-year growth curve model may have either accentuated or attenuated the amount of a bounce back effect and accelerated or decelerated its occurrence. Therefore, it remains to be determined (a) if a bounce back effect happens, (b) how strong it is, and (c) when exactly does it start occurring.

It is not that uncommon for teachers and service providers to meet sophomore students who are disillusioned and feel abandoned. The psychological experience of $2^{\text {nd }}$ year students has sometimes been described as the "sophomore slump" (e.g., Gump, 2007; Kennedy \& Lee Upcraft, 2010; Webb \& Cotton, 2018) - a period characterized by decreasing grades, academic 
satisfaction/interest, and increase thoughts of dropping out (Schreiner \& Pattengale, 2000).

However, the 2007 National Sophomore Experience Survey revealed that only $14 \%$ of students rated their $2^{\text {nd }}$ year as worse than their $1^{\text {st }}$ year (Schreiner, 2010). Longitudinal studies in twoyear colleges have also showed that the academic adjustment of only $10 \%$ of students significantly deteriorates (Duchesne, Ratelle, Larose, \& Guay, 2007), the career indecision of only $25 \%$ of students remains chronically high (Guay et al., 2006), and the self-efficacy of only $30 \%$ of students worsened during the $2^{\text {nd }}$ year (Larose, Ratelle, Guay, Senécal, \& Harvey, 2006).

The aforementioned longitudinal findings are consistent with the principle that the developmental trajectory of university students is marked by individual differences (principle \#1). As such, it appears that the $2^{\text {nd }}$ year experience could provide both increased opportunities for exploration, growth, and autonomy (i.e., bounce back effect) and increased risks of stagnation, disengagement, and chronical indecision (i.e., slump effect). As a result, the trajectory of academic achievement of students is likely to reflect the co-existence of a "bounce back effect" for many students and a "sophomore slump effect" for other students. Whether the academic trajectory of an average $2^{\text {nd }}$ year student is marked by a "bounce back effect" or a "sophomore slump effect", and just how strong the dominant effect really is, are questions in need of empirical investigation. As eloquently summarized by Kennedy and Lee Upcraft (2010, p. 39) research "that examines both grade point averages and attrition rates for sophomores, taking into consideration first-year grades, should be conducted". The next empirical illustration tries to fill this gap. Consistent with the principles that inter-individual differences in the developmental trajectory of achievement are real (principle \#1) and consequential (principle \#2), students with a stronger bounce back effect in their $2^{\text {nd }}$ year should be more likely to return for 
the $3^{\text {rd }}$ year. If so, the implications of our achievement as a process approach are far reaching to predict long-term academic success of university students (principle \#3).

\section{Empirical Illustration}

Overview. I examined the 3600 students (from the original sample of 4212) who returned for the $2^{\text {nd }}$ year. This time, the unit of analysis was changed to focus on yearly achievement and I analyzed admission GPA, $1^{\text {st }}$ year yearly GPA, and $2^{\text {nd }}$ year yearly GPA. This approach examined the achievement trajectory during the consecutive transitions from high school to the $1^{\text {st }}$ year and from the $1^{\text {st }}$ to the $2^{\text {nd }}$ year. Estimated sample mean and standard deviations are reported in Table S2 in the supplementary file. Mean-level analyses revealed a strong decline in grades from high school to the $1^{\text {st }}$ year $(d=-1.040,95 \% \mathrm{CI}=[-1.089,-0.990])$ and a small increase from the $1^{\text {st }}$ to the $2^{\text {nd }}$ year $(d=0.033,95 \% \mathrm{CI}=[-0.014,0.079]$. Rank-order stability was .651 from high school to the $1^{\text {st }}$ year and .779 from the $1^{\text {st }}$ to the $2^{\text {nd }}$ year. Consistent with past research, the relative positioning of students in the distribution was quite stable but the mean-level grades strongly decreased during the transition from high school to university and remained stable during the $2^{\text {nd }}$ year. Achievement manifested both relative rank-order stability and mean-level change.

Trajectory of achievement during the $1^{\text {st }}$ and $2^{\text {nd }}$ years. A piecewise growth model was performed to isolate and directly test the statistical significance of the change in yearly grades from high school to the $1^{\text {st }}$ year (slope \#1) and from the $1^{\text {st }}$ to the $2^{\text {nd }}$ year (slope \#2). A detailed explanation of model specification can be found in the supplementary file.

Parameter estimates of this model are reported in Table 2 and the predicted values are shown in Figure 3. The grades of students significantly decreased from high school to the $1^{\text {st }}$ year 
(slope \#1). They significantly increased from the $1^{\text {st }}$ to the $2^{\text {nd }}$ year, but to a small magnitude (slope \#2). The intercept positively and significantly correlated with slope \#1 (i.e., Matthew effect), thus showing that students who entered university with a higher admission GPA experienced more positive change (i.e., a smaller decline) during their $1^{\text {st }}$ year. Also, the slopes differed significantly across participants, thus showing that achievement trajectory was qualified by a significant amount of inter-individual differences.

Predicting $3^{\text {rd }}$ Year Retention. A distal binary outcome $\left(0=\right.$ not returning in fall of $3^{\text {rd }}$ year; $1=$ returned in fall of $3^{\text {rd }}$ year) was added to the piecewise growth model to examine if change in achievement from high school to the $1^{\text {st }}$ year (slope \#1) and from the $1^{\text {st }}$ to the $2^{\text {nd }}$ year (slope \#2) significantly predict $3^{\text {rd }}$ year retention. I tested two separate models to investigate the effects of slope \#1 and slope \#2 over and above point estimates in high school GPA (model 1) and $1^{\text {st }}$ year GPA (model 2), respectively (see supplementary file for model specifications).

As shown in Figure 5, the results of the two models slightly differed. When controlling for high school GPA (model 1), the change of academic achievement from high school to the $1^{\text {st }}$ year (slope \#1) and from the $1^{\text {st }}$ to the $2^{\text {nd }}$ year (slope \#2) were both significant predictors of $3^{\text {rd }}$ year retention. When controlling for the $1^{\text {st }}$ year GPA (model 2 ), only the change from the $1^{\text {st }}$ to the $2^{\text {nd }}$ year (slope \#2) significantly predicted $3^{\text {rd }}$ year retention. The effect size of the admission GPA and $1^{\text {st }}$ year GPA (Model 1 and $2:$ OR $=1.505$, Cohen's $d=0.225$ ) on $3^{\text {rd }}$ year retention was small. The effect size of slope \#1 was modest but significant when controlling for high school GPA (Model 1: OR $=1.714$, Cohen's $d=0.297$ ) and small but non-significant when controlling for $1^{\text {st }}$ year GPA (Model 2: OR $=1.130$, Cohen's $d=0.067$ ). In contrast, the effect size of slope \#2 was strong and significant when controlling for either high school GPA (Model 1: OR $=4.024$, Cohen's $d=0.768)$ or $1^{\text {st }}$ year GPA (Model 2: OR $=4.050$, Cohen's $\left.d=0.771\right)$. 
Of particular interest, the effect size of slope \#2 was significantly stronger than slope \#1

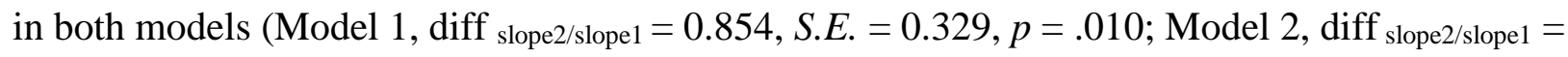
1.276$, S.E. $=0.381, p=.001)$. The effect size of slope \#2 was also significantly stronger than the effect size of point estimates in admission GPA (Model 1, diff slopez/intercept $=0.984$, S.E. $=0.204$, $p<.001)$ and $1^{\text {st }}$ year GPA (Model 2, diff slope $2 /$ intercept $=0.988$, S.E. $\left.=0.206, p<.001\right)$. Overall, change in academic achievement during $2^{\text {nd }}$ year was a stronger predictors of $3^{\text {rd }}$ year retention than change during $1^{\text {st }}$ year and point estimates of achievement (i.e., high school, $1^{\text {st }}$ year).

Key Implications. Students experience an achievement shock during the $1^{\text {st }}$ year but their achievement stabilizes and slightly improves during the $2^{\text {nd }}$ year. This finding provides evidence for a small yet statistically significant "bounce back effect". The achievement trajectory differs significantly across students (principle \#1) and, more importantly, these differences are consequential (principle \#2). Positive change in grades from the $1^{\text {st }}$ to the $2^{\text {nd }}$ year is a significant and unique predictor of $3^{\text {rd }}$ year retention. The effect sizes is strong and even stronger than the effect size of the point estimates of academic achievement (i.e., high school and $1^{\text {st }}$ year). Those with a stronger bouncing back during the $2^{\text {nd }}$ year are significantly more likely to continue their tertiary education the subsequent fall.

The added value of our achievement as a process approach are far reaching (principle \#3) because they extend beyond the $1^{\text {st }}$ year. Retention is typically envisioned as problem circumscribed to $1^{\text {st }}$ year students. In this sample, $15 \%$ of the students who started their $2^{\text {nd }}$ year did not return to start their $3^{\text {rd }}$ year. The academic struggles and retention problem of sophomores is just as worrisome as those of the frosh students (e.g., Sterling, 2018). Sophomores are equally in need of targeted interventions that could transform their $2^{\text {nd }}$ year of tertiary education into a "bouncing back" rather than "a slumping" experience. Academic achievement is a development 
story with important consequences beyond the $1^{\text {st }}$ year. The developmental trajectory of achievement not only predicts $3^{\text {rd }}$ year retention, but it significantly outperforms the typical predictors (e.g., Westrick et al., 2015) used to identify at risk students. Monitoring the achievement progress from the $1^{\text {st }}$ to the $2^{\text {nd }}$ year is required to obtain accrued precision in our effort to target students likely not to return for their $3^{\text {rd }}$ year. The new pieces of information, uncovered by the achievement as a process approach, should be used to raise awareness about the importance of bouncing back during the $2^{\text {nd }}$ year for long-term academic success.

\section{The Four Years at the University}

Inasmuch as sophomores have been under-researched in psychological science (Tobolowsky, 2008), it is fair to assert that even less attention has been dedicated to students during their $3^{\text {rd }}$ and $4^{\text {th }}$ year of tertiary education research. The lack of attention dedicated to the later years is troublesome insofar as students face increasing and time-bound pressure to prepare for a competitive, globalized, and ever-changing job market. With improved access and growing enrollment in undergraduate education, admission to graduate school has also become more demanding (Brubacher, 2017). Results of a recent study with 12,318 students revealed that approximately $14 \%$ of all students entering a public four-year institution abandoned after earning at least $75 \%$ of the credits needed to graduate (Mabel \& Britton, 2018). In other words, one-third of all dropouts happened in the later years of tertiary education. Late departure is more widespread than expected but perhaps not that surprising given the lack of research, policy, and intervention effort specifically dedicated to junior and senior students.

Timely graduation is also of paramount importance for administrators, policy makers, parents, and students themselves (DesJardins, Ahlburg, \& McCall, 2002). Most students entering 4-year institutions do not graduate within the customary four years need to complete the 
requirements of their program. In a study of 3072 students recruited across fifteen 4-year institutions, only $33 \%$ earned a timely diploma immediately after their fourth year (Allen \& Robbins, 2010). Taking an extra year to graduate can be costly for the institutions, the students, and their families because it results in increased tuition and cost of living fees and a full-year loss in post-graduation incomes.

Despite the potential benefits of timely graduation, limited research has examined how the experience of students during their four years at the university can influence the time taken to complete their degree. Of particular importance, it appears that academic achievement during the first year has the largest direct effect (over and above motivation, major congruence, high school achievement, and many students' characteristics) on timely graduation (Allen \& Robbins, 2010). Similarly, results of a large study of 12,069 first-year students (Yue \& Fu, 2017) revealed that academic achievement during the years at the university is the strongest predictor, accounting for $46 \%$ of the $55 \%$ of explained variance in timely graduation, over and above both time-invariant predictors (e.g., gender, first generation status, high school GPA) and time varying predictors (e.g., enrollment intensity, major change).

In the final empirical illustration, I explored the developmental course of achievement across all four years of tertiary education. Here again, the consequence of inter-individual differences in the developmental course of academic achievement should be far reaching (principle \#3). More precisely, it was hypothesized that continued improvement in achievement during the $2^{\text {nd }}, 3^{\text {rd }}$, and $4^{\text {th }}$ year should help students graduate in four years (i.e., timely graduation) over and above their level of achievement in high school and during the $1^{\text {st }}$ year.

\section{Empirical Illustration}


Overview. I examined the 3136 students (out of the original sample of 4212) who returned for the $3^{\text {rd }}$ year using yearly GPA as the unit of analysis. The admission GPA and the yearly average of grades obtained each year were analyzed to focus on the entire duration of a four-year program. Estimated sample mean and standard deviations are reported in Table S3 (see supplementary file). Mean-level analyses revealed a strong decline in grades from high school to the $1^{\text {st }}$ year $(d=-1.030,95 \% \mathrm{CI}=[-1.083,-0.978])$ and a small yearly increase starting during the $2^{\text {nd }}$ year: from the $1^{\text {st }}$ to the $2^{\text {nd }}$ year $(d=0.106,95 \% \mathrm{CI}=[0.057,0.156])$, from $2^{\text {nd }}$ to the $3^{\text {rd }}$ year $(d=0.075,95 \% \mathrm{CI}=[0.026,0.125])$, and from the $3^{\text {rd }}$ to the $4^{\text {th }}$ year $(d=0.141,95 \% \mathrm{CI}=$ $[0.091,0.191])$. Rank-order stability was .637 from high school to the $1^{\text {st }}$ year and $.758, .770$, and .801 in each of the subsequent years. The rank-order stability coefficients were moderate-tostrong. The average grades of students strongly decreased during the transition from high school to university but progressively increased from the $2^{\text {nd }}$ year to the $4^{\text {th }}$ year. Overall, academic achievement manifested both relative rank-order stability and mean-level change.

Trajectory of achievement across 4 years. A piecewise growth curve model was performed in order to isolate and directly test the statistical significance of the change from high school to the $1^{\text {st }}$ year (slope \#1) and from the $2^{\text {nd }}$ to the $4^{\text {th }}$ year (slope \#2). A detailed explanation of model specification can be found in the supplementary file.

Parameter estimates of this model are reported in Table 3 and the predicted values are shown in Figure 6. The grades of students significantly decreased by 1.60 points from high school to the $1^{\text {st }}$ year (slope \#1) before increasing by 0.18 point each year during the $2^{\text {nd }}, 3^{\text {rd }}$, and $4^{\text {th }}$ year (slope \#2). Slope \#1 and slope \#2 significantly differed across participants. Finally, the intercept positively and significantly correlated with slope \#1 (i.e., Matthew effect), thus showing that the students who entered university with a higher admission GPA experienced 
more positive change (i.e., a smaller decline) during their $1^{\text {st }}$ year. However, this trend reverted to a small negative correlation between the intercept and slope \#2, suggesting that people with higher admission GPA experienced smaller increase in their grades beyond the $1^{\text {st }}$ year.

Predicting Timely Graduation. A distal binary outcome $\left(0=\right.$ not graduating after $4^{\text {th }}$ year; $1=$ diploma awarded after $4^{\text {th }}$ year) was added to the piecewise growth model to examine if change in academic achievement from high school to the $1^{\text {st }}$ year (slope \#1) and from the $2^{\text {nd }}$ to the $4^{\text {th }}$ year (slope \#2) significantly predict timely graduation. We tested two separate models to investigate the effects of slope \#1 and slope \#2 over and above high school GPA (model 1) and $1^{\text {st }}$ year GPA (model 2), respectively (see supplementary file for model specifications).

The results of the two models are presented in Figure 7. When controlling for either high school GPA (model 1) or $1^{\text {st }}$ year GPA (model 2), the change of academic achievement from high school to the $1^{\text {st }}$ year (slope \#1) and from the $2^{\text {nd }}$ to the $4^{\text {th }}$ year (slope \#2) were both significant predictors of timely graduation. The effect sizes of admission GPA and $1^{\text {st }}$ year GPA (Model 1: OR $=1.386$, Cohen's $d=0.180$; Model 2: OR $=1.428$, Cohen's $d=0.196$ ) on timely graduation were small. The effect size of slope \#1 was moderate when controlling for high school GPA (Model 1: OR $=2.158$, Cohen's $d=0.424$ ) and small when controlling for $1^{\text {st }}$ year GPA (Model 2: OR $=1.426$, Cohen's $d=0.196)$. In contrast, the effect size of slope \#2 was strong and significant when controlling for high school GPA (Model 1: OR $=6.120$, Cohen's $d=$ 0.999) or $1^{\text {st }}$ year GPA (Model 2: OR $=6.142$, Cohen's $\left.d=1.00\right)$. Of particular interest, the effect size of slope \#2 was significantly stronger than slope \#1 in both models (Model 1, diff slope2/slope $1=1.042$, S.E. $=0.215, p<.001 ;$ Model 2, diff slope2/slope1 $=1.460$, S.E. $=0.243, p<.001)$. The effect size of slope \#2 was also significantly stronger than the effect size of admission GPA $($ Model 1, diff slope $2 /$ intercept $=1.485$, S.E. $=0.156, p<.001)$ and $1^{\text {st }}$ year GPA $($ Model 2, diff 
slope 2 intercept $=1.495$, S.E. $=0.153, p<.001)$. Overall, change in academic achievement during the $2^{\text {nd }}, 3^{\text {rd }}$, and $4^{\text {th }}$ year was a stronger predictor of timely graduation than point estimates of achievement and change from high school to the $1^{\text {st }}$ year.

Key Implications. Students experience an "achievement shock" during the $1^{\text {st }}$ year, followed by continued improvement in grades during the $2^{\text {nd }}, 3^{\text {rd }}$, and the $4^{\text {th }}$ years. The academic achievement of an average student is characterized by a bounce back effect starting during the $2^{\text {nd }}$ year. However, this bounce back effect (improvement of 0.55 points from the $2^{\text {nd }}$ to the $4^{\text {th }}$ year) does not erase the initial achievement shock (decrease of 1.60 points) experienced during the $1^{\text {st }}$ year. Furthermore, not everyone experience this bounce back effect considering that the four-year trajectory of achievement significantly differs across students (principle \#1).

The implications of our achievement as a process approach are consequential (principle \#2) and far reaching (principle \#3) because the developmental story of achievement is a significant and a better predictor of timely graduation. More precisely, students who experience a steeper improvement in achievement after the $1^{\text {st }}$ year are more likely to finish their course-load and graduate within four years. The trajectory of achievement not only significantly predicts timely graduation but it also outperforms the typical point estimates of achievement (Allen \& Robbins, 2010). Researchers, service providers, and administrators need to allocate resources to better understand the psychosocial characteristics of the students whose achievement bounces back after the academic shock of the $1^{\text {st }}$ year. This knowledge would help identify and intervene one the prime factors leading up to gradual and continuous improvements in academic achievement. Improvement from the $2^{\text {nd }}$ to the $4^{\text {th }}$ year is key for long-term academic success. Monitoring the achievement progress throughout the four years is required to obtain accrued precision in our effort to identify students with greater risk of delayed graduation. Conceiving 
achievement as a process is needed to inform research, intervention, and policy because the implications are far reaching and generalize across frosh, sophomore, junior, and senior students.

\section{Broader Implications of the Achievement as a Process Approach}

As shown across three empirical illustrations, academic achievement is a developmental story with far reaching importance for the long-term success of students. Reconceptualising achievement as a process has many implications for the management, services, policies, and research agenda of many people working to promote the success of students. In this section, six broader implications stemming from the achievement as a process approach are delineated.

\section{Changing the Focus of our Monitoring Systems}

First, the results of our empirical illustrations suggest that universities need to reconsider how they monitor the grades of students. Most universities identify at-risk students based on their admission GPA and grades earned during the $1^{\text {st }}$ semester (or $1^{\text {st }}$ year). However, my findings showed that these typical predictors are outperformed by changes in grades. Therefore, systems that track the development of grades over time are needed to help curbing school dropout after the $1^{\text {st }}$ year. Changes in achievement could be incorporated into a refined predictive model to switch from a static to a dynamic progress-based monitoring system.

The achievement as a process approach highlights the importance of early detection of atrisk students. In most universities, the grades of students are monitored only after the $1^{\text {st }}$ semester. Therefore, we know very little about the developmental story of the grades earned within the $1^{\text {st }}$ semester. Research is needed to examine if the academic shock is mostly attributable to extremely poor results on the first set of midterm exams. To do so, administrators could enforce the idea that midterm grades should be rapidly and systematically logged into a 
learning management system with built-in analytics. Creating an automated monitoring system capable of estimating the change between high school GPA and results on the midterm exams (rather than just the results from the midterms) would facilitate detection of students as soon as the first signs of difficulties start appearing. Early interventions, right after the first midterms, may help students to prepare for their final exams and curb their academic shock sooner rather than later. Such a progress-based monitoring system - based on change rather than a point estimate of achievement - would offer the infrastructure to scale-up early intervention efforts.

\section{Studying the Predictors of Academic Achievement Change}

Second, we need to differentiate the predictors of point estimates of achievement (e.g., yearly GPA) from the predictors of change in achievement. Individual differences in achievement and individual differences in trajectory of achievement operate at two distinct but potentially related levels of analysis (e.g., Mehl \& Conner, 2012). Assuming that each set of outcomes is predicted by the exact same predictors appears improbable just as much as advancing that point estimate and trajectories are predicted by an entirely different network of predictors (e.g., Dalal et al., 2014; Kljajic \& Gaudreau, 2018); both similarities and differences are to be expected and need to be uncovered. Psychological, educational, and even organizational sciences have accumulated vast knowledge explaining individual differences in achievement (e.g., Credé \& Kuncel, 2008; Credé, Roch, \& Kieszczynka, 2010; Hattie, 2009; Richardson et al., 2012; Schneider \& Preckel, 2017). Far less attention has been allocated to identify why achievement changes over time - and differentially changes for different individuals.

Two lines of systematic inquiry are required to move forward the achievement as a process approach. One the one hand, researchers may start by examining if known correlates of individual differences in achievement also predict individual differences in the trajectory of 
achievement. Studies like these can be found with students in elementary and secondary schools (e.g., Fu, Chen, Wang, \& Yang, 2016; Mok, McInerney, Zhu, \& Or, 2014; Murayama, Pekrun, Lichtenfeld, \& vom Hofe, 2013; Suarez-Orozco et al., 2010). Such investigations will shed light into whether known predictors generalize across levels of analysis. On the other hand, researchers may venture into theory elaboration to specifically understand what accounts for individual differences in achievement trajectories. Such investigations will identify new mechanisms that uniquely explicate achievement trajectories without necessarily predicting individual differences in achievement. Both lines of inquiry, once integrated into a unified t, will foster a novel understanding of what predict point estimate without predicting achievement trajectory (and vice versa). Such an understanding will help identify risk and protective factors to be included in interventions specifically designed to reduce individual differences in achievement, buffer the decreases in achievement during the $1^{\text {st }}$ year, boost the bounce back effect of the $2^{\text {nd }}$ year, or all of the above.

\section{Studying the Consequences of Academic Achievement Change}

Third, we need to specify the psychological consequences of the academic shock experienced by $1^{\text {st }}$ year university students and the slumping effect experienced by some sophomores. My empirical illustrations showed, for example, that the academic shock matters as it predicts $2^{\text {nd }}$ year retention. What is left to clarify is the precise psychological mechanisms through which the academic shock translates into dropout.

Psychological science is in a privileged position to explicate how within-person changes in academic achievement can lead to long-term academic success. Several theories (e.g., Carver \& Scheier, 1998; Higgins, 1987; Weiner, 2010) work under the assumption that discrepancy between past and actual states and discrepancy between current and desired states both play a 
central role in the regulation of behaviors and emotions (for reviews, see Harkin et al., 2016;

Kelly, Mansell, \& Wood, 2015). Students enter university with performance expectancies largely derived from their past achievement. They think they will succeed and receive high marks but most of them soon realize that keeping the same level of achievement may be unattainable and unrealistic. Discrepancy between past/desired and actual performance will likely result in negative emotions and search for causal explanations. Depending on their causal attributions, students will experience less or more detrimental emotional states likely to influence their selfefficacy and subsequent effort, which will either facilitate or hinder their subsequent performance (e.g., Weiner, 2010). Depending on their implicit theories, they will also maintain or reconsider their beliefs about their capacity to improve, bounce back, and eventually succeed in the pursuit of their academic goals (e.g., Yeager \& Dweck, 2012). Intervention studies designed to change causal attributions and mindset of students have been found to play a causal role in increasing subsequent achievement and the likelihood of retention (e.g., Lazowski \& Hulleman, 2016; Silverman \& Cohen, 2014). The academic shock, that typifies the $1^{\text {st }}$ year of tertiary education, needs to be revisited in light of sound psychological theories capable of delineating the precise mechanisms through which more positive changes in academic achievement lead to long-term academic success of university students.

Future research could also explore what goes in the mind and the heart of students when they experience significant declines in their academic achievement at different points in their undergraduate lives. The decision to persevere or to withdraw from tertiary education is not solely attributable to changes in academic achievement (e.g., Alarcon \& Edwards, 2013; Robbins et al., 2009). There is something missing in our theoretical understanding of why and how the academic shock of the $1^{\text {st }}$ year increases the likelihood of school dropout. I contend that the 
relationship is neither direct nor magic. The development of academic achievement is part of a complex psychological system in which the novel school-related experiences of university students reciprocate with their already existing but evolving identity, needs, goals, motives, beliefs about the self and the world, social connectedness, and emotional experiences. The changing, reciprocal, transactional, and potentially recurrent patterns experienced by students during the transition create new "relational meaning" (i.e., the relation between me and school) through which they reconsider their school satisfaction and intention to persevere; it changes their narratives (e.g., Silverman \& Cohen, 2014; Yeager \& Walton, 2011). A stronger academic shock should proportionally create a narrative entrenched with doubts, fears, worries, and anger. In contrast, a smaller academic shock should proportionally act to build and reinforce a narrative in which identity, goals, motives, beliefs, and feelings are linked to an overall positive experience of being a university student. A closer attention to the narrative attached with the development of academic achievement would help understand how and why decrease and increase in grades respectively relate to decreased and increased rates of long-term success.

\section{Intervening at Various Points in the Development of Academic Achievement}

Fourth, current interventions disproportionally target $1^{\text {st }}$ year students to facilitate their transition into tertiary education and curb the retention problem. However, as shown in our empirical illustrations, dropping out of university is not limited to $1^{\text {st }}$ year students. On the one hand, $2^{\text {nd }}$ year students with a stronger bouncing back effect - in contrast to a slumping experience - are more likely to return beyond their $2^{\text {nd }}$ year. On the other hand, a steeper improvement in academic achievement during the sophomore up to the senior years maximizes the likelihood that students graduate in a timely manner. Researchers, administrators, and service providers should seriously consider widening the availability and scope of services offered to 
students beyond the $1^{\text {st }}$ year in order to promote their long-term academic success (Hunter et al., 2009). Rather that criticizing the current intervention model - which has been implemented with wholeheartedly good intentions - I would rather highlight that the achievement as a process approach offers a springboard to identify multiple windows of opportunity for interventions.

Positioning the trajectory of achievement as the primary outcome of interventions would open up a new way of picturing the importance of timing in our work with university students. Different timing of an intervention may create different types of effect in the developmental course of academic achievement. Although timing matters, it is rarely taken into consideration in the design and evaluation of psychological interventions in tertiary education. Intervening before or as soon as possible during the $1^{\text {st }}$ semester may offer the best possible chance of minimizing the academic shock of $1^{\text {st }}$ year students. Such primary prevention initiatives could indeed improve the performance of students during their initial set of midterm exams, thus offering the best possible chances of minimizing the drop between their admission GPA and $1^{\text {st }}$ semester GPA. Not all institutions have the resources and infrastructure to intervene before or immediately after students start their courses. Not all students will be willing to participate in interventions before experiencing their first signs of difficulties. When such early interventions are not possible, launching secondary prevention initiatives after the first set of midterms may help students better prepare for their final exams, thus also minimizing the drop between admission GPA and $1^{\text {st }}$ semester GPA. Taken together, the fall of the $1^{\text {st }}$ year offers two naturally conducive windows of opportunity to intervene. Students randomized (i.e., experimental trials) or participating (i.e., quasi-experiment) in early initiatives may end up with a smoothened academic shock likely to increase retention. 
The typical intervention model not only disproportionally targets $1^{\text {st }}$ year students, but it also overly focuses on the $1^{\text {st }}$ semester. Treating achievement as a developmental story has widespread practical implications because I advance that students receiving no intervention during the $1^{\text {st }}$ semester are not necessarily doomed for long-term academic failure. The winter term of the $1^{\text {st }}$ year offers a third window of opportunity for early tertiary prevention initiatives. Immediately after the $1^{\text {st }}$ semester, administrators and service providers have access to the grades from the $1^{\text {st }}$ semester. As such, they often launch targeted interventions with students who have failed several courses or did not attain minimal academic requirements (e.g., probation). We contend that students with "good grades" but a strong achievement shock should also be reached out for targeted interventions. A student may have earned a $\mathrm{B}+$ average (a full point above the population average on campus) in the fall but nonetheless feel distressed and disillusioned after having experienced a $15 \%$ drop compared to his/her high school average. Intervening with such students during the $2^{\text {nd }}$ semester could potentially help to buffer subsequent achievement decline and perhaps even accelerate the arrival of a bounce back effect.

The sophomore year is another critical turning point (e.g., Schaller, 2010; Webb \& Cotton, 2018). However, those who return often receive limited support because academic difficulties and retention problems are often perceived as being specific to $1^{\text {st }}$ year students. Nonetheless, $2^{\text {nd }}$ year students are often mentally underprepared for the new challenges of transitioning from a general curriculum to the specific language, knowledge, and skills of their major. Based on the achievement as a process approach, I contend that the $2^{\text {nd }}$ year offers yet another window of opportunity for both universal and targeted interventions. Intervening during the $2^{\text {nd }}$ year could increase the number of students experiencing a bounce back effect and decrease the number of students experiencing a slumping effect. $2^{\text {nd }}$ year interventions could not 
only improve the academic achievement of students, but it could potentially increase the rates of $3^{\text {rd }}$ year retention and timely graduation after four years.

By conceiving academic achievement as a dynamic process, the achievement as a process approach provides the needed rationale to revisit when and with whom we should intervene to promote long-term success of students. Different types of intervention delivered at different points in time could also yield a different amount of desirable outcomes. Therefore, a systematic research agenda - one paying attention to potential time $\times$ types of intervention effects (e.g., Ishitani, 2016; Pan, Guo, Alikonis, \& Bai, 2008) - should be put in place to take advantage of the many windows of opportunity to offer different promotion, prevention, and intervention programs to frosh, sophomore, junior, and senior students.

\section{Toward a Multilevel Organizational and Historical Approach to Academic Success}

My empirical illustrations reported the case of one Canadian university with data collected in 2006. This is indeed limitative. Institutions differ on many potentially important organizational factors: Access policies, selectivity criteria, grading policies, number of students enrolled, student-faculty ratio, research funding, enrollment in graduate school, admission GPA, etc. As such, researchers should focus on the students from each university - like I did in the current empirical illustrations - just as much as they should investigate the generalizable features of all students within a larger network of institutions. The achievement as a process approach appears promising to extend multilevel models of retention (e.g., Chen, 2012; Oseguera \& Rhee, 2009; Titus, 2004). Adding a developmental component could further our understanding of how student-level and institutional-level factors interact to predict student-level and institution-level achievement outcomes. For example, it would be interesting to investigate whether universities with better student-faculty ratio are better equipped to tone down the academic shock of $1^{\text {st }}$ year 
students and to accelerate the bounce back effect during $2^{\text {nd }}$ year. Similarly, it would be important to expend on previous multilevel research (e.g., Titus, 2004) to determine if students in selective universities (i.e., higher admission GPA) experience a greater, comparable, or lower achievement shock during their $1^{\text {st }}$ year. Retention and graduation rates fluctuate across institutions. As such, a multilevel extension of the achievement as a process approach would offer a theoretical roadmap to investigate which predictors of retention and timely graduation generalize across institutions with different organizational characteristics.

Psychological science generally studies the person during one specific historical period. Universities are storing a gigantesque amount of data describing the developmental course of academic achievement from countless students across many cohorts since many decades. Institutions and their students have significantly evolved across the history of tertiary education (Brubacher, 2017). Many of the potentially important organizational factors - that currently varies across institutions - have also changed across the course of history. Institutions of the 1990s differed from our current tertiary education institutions on many potentially important organizational factors. For example, universities have witnessed a significantly growth and diversification in enrollment. Historical changes in student-faculty ratio, increases in tuition fees, and grade inflation in high school may or may not have contributed at aggravating the achievement shock of $1^{\text {st }}$ year students and the sophomore slump of $2^{\text {nd }}$ year students. Future research could delve into some of these fascinating questions in order to understand which of the social, economic, and cultural changes - within which our educational system operates - have successfully or unsuccessfully promoted students' access and retention in tertiary education.

Institutions are competing to attract the best students and to help them graduate. As a result, the tertiary education community often overinvests in institutional retention rather than 
sharing the wisdom of their successful initiatives to promote retention throughout the network of institutions. In a study conducted in the United States, Allen and his colleagues (2008) found that $38 \%$ of non-returning students were transfers rather than real dropouts. Like most research on retention (Robbins et al., 2004), my empirical illustrations did not account for institution transfers. Unfortunately, universities and colleges in Canada do not share and keep track of transfers across institutions. Not all students are admitted in the city and school of their choice. Securing good grades during the $1^{\text {st }}$ year may facilitate the transfer of very successful students into the school of their choice. As a result, some frosh students with a small achievement shock may decide to pursue their education in a new school and would therefore end up being mistakenly categorized as $2^{\text {nd }}$ year dropouts. A truly multilevel organizational model of academic success will require that the Canadian higher education sector imitates the United States by creating a National Student Clearinghouse to track the enrollment, transfers, and degree attainment of students across the country.

\section{Rewarding Students Based on Progress rather than Cumulative Achievement}

Recent years have seen the appearance of a movement to promote personal growth in education (A. J. Martin, 2015). Theory-driven research on incremental/growth mindset (Yeager \& Dweck, 2012), personal best goals (Martin \& Elliot, 2016), self-improvement goals (Elliot, Murayama, Kobeisy, \& Lichtenfeld, 2015), internal scheme of reference to define and evaluate self-concept (Marsh, Xu, \& Martin, 2012), academic momentum (Martin et al., 2013), and personal goal progress (Wiese, 2007) are just a few leading examples of the many growth-related ideas in our contemporary psychological science. All of these constructs have in common a within-person perspective in which achievement is defined using some internal/personal 
standards. The achievement as a process approach - which focuses on the developmental story of academic achievement - contributes to the current zeitgeist.

Organizational, cognitive, and educational researchers are also paying more attention to alternate ways of defining and measuring achievement. In organizational sciences, researchers have recently highlighted the need to differentiate typical (i.e., average across time and performance episodes) and episodic achievement which fluctuates across tasks, time of the day, and day of the week (e.g., Beal et al., 2005; Dalal et al., 2014). Specific research programs have emerged to identify the characteristics of happy/productive versus unhappy/unproductive days in the lives of workers (e.g., Bakker \& Daniels, 2013). In cognitive sciences, researchers reiterated the need to make a clear distinction between performance and learning (Soderstrom \& Bjork, 2015). On the one hand, performance represents the level of achievement achieved by a person soon after or while being taught something relatively new. Scores on exams - which form the basis upon which we calculate achievement in education - are a good example of what cognitive researchers would call performance. On the other hand, learning represents the long-term retention and capacity to reuse the knowledge and skills in different contexts. Scores on an unexpected pop-test two weeks after a real exam would be a good example of a task measuring learning (e.g., delayed memory). This differentiation is more than semantic quibbling because performance and learning are related but distinct outcomes potentially caused and influenced by both similar and dissimilar cognitive processes and psychosocial factors (e.g., Dunlosky, Rawson, Marsh, Nathan, \& Willingham, 2013; Murayama \& Elliot, 2011).

On a related note, educational researchers and policy makers are now expressing a growing interest toward learning outcomes (Shavelson, Zlatkin-Troitschanskaia, \& Mariño, 2018). Between their $1^{\text {st }}$ and $4^{\text {th }}$ year, university students are expected to acquire and accumulate 
knowledge and skills such as creative thinking, critical thinking, and problem solving. The capacity to use knowledge and skills should naturally improve throughout tertiary education and prepare students to enter graduate school or the job market. Earning good grades is seen as an insufficient demonstration of learning insofar as students must also demonstrate improvements in knowledge and skills at the end of their tertiary education. This particular focus on mastery, improvement, and learning - which requires a focus on the developmental story of the student appears consistent with the achievement as a process approach put forward in this article.

\section{Conclusion}

Universities invest considerable resources to optimize learning, achievement, and longterm success of their students. The countless hours and four years spent by university students have a long-lasting impact on their personal and professional competencies. Repositioning the academic achievement as a developmental process has numerous implications to improve the services and even the rewards offered to our students. Curbing the academic shock of $1^{\text {st }}$ year students and helping them to bounce back in their $2^{\text {nd }}$ year has the potential to improve retention and timely graduation.

Three general principles were delineated and illustrated with empirical data with the ultimate goal of steering theory elaboration, research, and interventions in novel directions. From Babe Ruth to Aaron Judge and Henry Ford to Bill Gates, our society has entertained a long-held admiration for individuals who perform significantly better than others. Even today, rankordering remains the yardstick upon which athletes, students, and employees are assessed and held accountable. Knowing that someone performs better than others is insufficient to help us understand and intervene on the processes by which achievement builds over time and fluctuates across contexts and situations. As a society, we know too little about the episodic ups and downs 
and long-term developmental trajectories of human achievement. In this article, I favored a developmental definition of success that centers on learning, improvement, and personal progress. The implications of the achievement as a process approach are far reaching - not limited to tertiary education - as they could easily be applied across many areas of psychological science (e.g., development of expertise, aging, learning) and related fields (e.g., K-12 education, sport, work, arts).

\section{References}

Alarcon, G. M., \& Edwards, J. M. (2013). Ability and motivation: Assessing individual factors that contribute to university retention. Journal of Educational Psychology, 105, 129-137. doi:10.1037/a0028496

Allen, J., \& Robbins, S. (2010). Effects of interest-major congruence, motivation, and academic performance on timely degree attainment. Journal of Counseling Psychology, 57, 23-35. doi:10.1037/a0017267

Allen, J., Robbins, S., Casillas, A., \& Oh, I.-S. (2008). Third-year college retention and transfer: Effects of academic performance, motivation, and social connectedness. Research in Higher Education, 49, 647-664. doi:10.1007/s11162-008-9098-3

Attewell, P., Heil, S., \& Reisel, L. (2012). What is academic momentum? And does it matter? Educational Evaluation and Policy Analysis, 34, 27-44. doi:10.3102/0162373711421958

Baker, R. W., \& Siryk, B. (1984). Measuring adjustment to college. Journal of Counseling Psychology, 31, 179-189. doi:10.1037//0022-0167.31.2.179

Bakker, A. B., \& Daniels, F. S. (2013). A day in the life of a happy worker. New York, NY: Psychology Press. 
Bandura, A. (2001). Social cognitive theory: An agentic perspective. Annual Review of Psychology, 52, 1-26. doi:10.1111/1467-839x.00024

Barbera, S. A., Berkshire, S. D., Boronat, C. B., \& Kennedy, M. H. (2018). Review of undergraduate student retention and graduation since 2010: Patterns, predictions, and recommendations for 2020. Journal of College Student Retention: Research, Theory \& Practice, 1521025117738233. doi:10.1177/1521025117738233

Beal, D. J., Weiss, H. M., Barros, E., \& MacDermid, S. M. (2005). An episodic process model of affective influences on performance. Journal of Applied Psychology, 90, 1054-1068. doi:10.1037/0021-9010.90.6.1054

Brubacher, J. (2017). Higher education in transition: History of American colleges and universities: Routledge.

Bruffaerts, R., Mortier, P., Kiekens, G., Auerbach, R. P., Cuijpers, P., Demyttenaere, K., . . . Kessler, R. C. (2018). Mental health problems in college freshmen: Prevalence and academic functioning. Journal of Affective Disorders, 225, 97-103. doi:10.1016/j.jad.2017.07.044

Carver, C. S., \& Scheier, M. F. (1998). On the self-regulation of behavior. New York: Cambridge University Press.

Caspi, A., Roberts, B. W., \& Shiner, R. L. (2005). Personality development: Stability and change. Annual Review of Psychology, 56, 453-484. doi:10.1146/annurev.psych.55.090902.141913

Chen, R. (2012). Institutional characteristics and college student dropout risks: A multilevel event history analysis. Research in Higher Education, 53, 487-505. doi:10.1007/s11162011-9241-4 
Chou, C.-P., Yang, D., Pentz, M. A., \& Hser, Y.-I. (2004). Piecewise growth curve modeling approach for longitudinal prevention study. Computational Statistics \& Data Analysis, 46, 213-225. doi:10.1016/S0167-9473(03)00149-X

Corcoran, R. P., \& O'Flaherty, J. (2017). Longitudinal tracking of academic progress during teacher preparation. British Journal of Educational Psychology, n/a-n/a. doi:10.1111/bjep.12171

Credé, M., \& Kuncel, N. R. (2008). Study habits, skills, and attitudes: The third pillar supporting collegiate academic performance. Perspectives on Psychological Science, 3, 425-453. doi:10.1111/j.1745-6924.2008.00089.x

Credé, M., \& Niehorster, S. (2012). Adjustment to college as measured by the student adaptation to college questionnaire: A quantitative review of its structure and relationships with correlates and consequences. Educational Psychology Review, 24, 133-165. doi:10.1007/s10648-011-9184-5

Credé, M., Roch, S. G., \& Kieszczynka, U. M. (2010). Class attendance in college: A metaanalytic review of the relationship of class attendance with grades and student characteristics. Review of Educational Research, 80, 272-295. doi:10.3102/0034654310362998

Curran, P. J., Obeidat, K., \& Losardo, D. (2010). Twelve frequently asked questions about growth curve modeling. Journal of Cognition and Development, 11, 121-136. doi:10.1080/15248371003699969

Dalal, R. S., Bhave, D. P., \& Fiset, J. (2014). Within-person variability in job performance: A theoretical review and research agenda. Journal of Management, 40, 1396-1436. doi:10.1177/0149206314532691 
DesJardins, S. L., Ahlburg, D. A., \& McCall, B. P. (2002). A temporal investigation of factors related to timely degree completion. The Journal of Higher Education, 73, 555-581. doi:10.1080/00221546.2002.11777168

Duchesne, S., Ratelle, C. F., Larose, S., \& Guay, F. (2007). Adjustment trajectories in college science programs: Perceptions of qualities of parents' and college teachers' relationships. Journal of Counseling Psychology, 54, 62-71. doi:10.1037/0022-0167.54.1.62

Dunlosky, J., Rawson, K. A., Marsh, E. J., Nathan, M. J., \& Willingham, D. T. (2013). Improving students' learning with effective learning techniques: Promising directions from cognitive and educational psychology. Psychological Science in the Public Interest, 14, 4-58. doi:10.1177/1529100612453266

Elliot, A., Murayama, K., Kobeisy, A., \& Lichtenfeld, S. (2015). Potential-based achievement goals. British Journal of Educational Psychology, 85, 192-206. doi:10.1111/bjep.12051

Evans, C., Kandiko Howson, C., \& Forsythe, A. (2018). Making sense of learning gain in higher education. Higher Education Pedagogies, 3, 1-45. doi:10.1080/23752696.2018.1508360

Finnie, R., \& Martinnello, F. (2010). I lost my scholarship: Changes in grades from high school to first year university. In R. Finnie, M. Frenette, R. E. Mueller, \& A. Sweetman (Eds.), Pursuing higher education in Canada: Economic, social, and policy dimensions (pp. 1542). Montreal: McGill-Queen's University Press.

Fong, C. J., Davis, C. W., Kim, Y., Kim, Y. W., Marriott, L., \& Kim, S. (2016). Psychosocial factors and community college student success. Review of Educational Research, 87, 388-424. doi:10.3102/0034654316653479 
Fu, R., Chen, X., Wang, L., \& Yang, F. (2016). Developmental trajectories of academic achievement in Chinese children: Contributions of early social-behavioral functioning. Journal of Educational Psychology, 108, 1001-1012. doi:10.1037/edu0000100

Galotti, K. M. (1999). Making a" major" real-life decision: College students choosing an academic major. Journal of Educational Psychology, 91, 379. doi:10.1037/00220663.91 .2 .379

Graunke, S. S., \& Woosley, S. A. (2005). An exploration of the factors that affect the academic success of college sophomores. College Student Journal, 39, 367-376.

Guay, F., Ratelle, C. F., Senecal, C., Larose, S., \& Deschenes, A. (2006). Distinguishing developmental from chronic career indecision: Self-efficacy, autonomy, and social support. Journal of Career Assessment, 14, 235-251. doi:10.1177/1069072705283975

Gump, S. E. (2007). Classroom research in a general education course: Exploring implications through an investigation of the sophomores slump. The Journal of General Education, 56, 105-125. doi:10.1353/jge.2007.0020

Harackiewicz, J. M., \& Priniski, S. J. (2018). Improving student outcomes in higher education: The science of targeted intervention. Annual Review of Psychology, 69, 409-435. doi:10.1146/annurev-psych-122216-011725

Harkin, B., Webb, T. L., Chang, B. P. I., Prestwich, A., Conner, M., Kellar, I., . . Sheeran, P. (2016). Does monitoring goal progress promote goal attainment? A meta-analysis of the experimental evidence. . Psychological Bulletin, 142, 198-229. doi:10.1037/bul0000025

Hattie, J. A. C. (2009). Visible learning: A synthesis of over 800 meta-analyses relating to achievement. New York, NY: Routledge. 
Higgins, E. T. (1987). Self-discrepancy: A theory relating self and affect. Psychological Review, 94, 319-340. doi:10.1037//0033-295x.94.3.319

Hunter, M. S., Tobolowsky, B. F., Gardner, J. N., Evenbeck, S. E., Pattengale, J. A., Schaller, M. A., \& Schreiner, L. A. (2009). Helping sophomores succeed: Understanding and improving the second year experience. San Francisco, CA: Jossey-Bass.

Hurst, C. S., Baranik, L. E., \& Daniel, F. (2013). College student stressors: A review of the qualitative research. Stress and Health, 29, 275-285. doi:10.1002/smi.2465

Ishitani, T. T. (2016). Time-varying effects of academic and social integration on student persistence for first and second years in college: National data approach. Journal of College Student Retention: Research, Theory \& Practice, 18, 263-286. doi:10.1177/1521025115622781

Kelly, R. E., Mansell, W., \& Wood, A. M. (2015). Goal conflict and well-being: A review and hierarchical model of goal conflict, ambivalence, self-discrepancy and self-concordance. Personality and Individual Differences, 212-229. doi:10.1016/j.paid.2015.05.011

Kennedy, K., \& Lee Upcraft, M. (2010). Keys to student success: A look at the literature. In M. S. Hunter, B. F. Tobolowsky, J. N. Gardner, S. E. Evenbeck, J. A. Pattengale, M. A. Schaller, \& L. A. Schreiner (Eds.), Helping sophomores succeed: Understanding and improving the second-year experience (pp. 30-42). San Francisco, CA: Jossey-Bass.

Kim, Y.-S., Petscher, Y., Schatschneider, C., \& Foorman, B. (2010). Does growth rate in oral reading fluency matter in predicting reading comprehension achievement? Journal of Educational Psychology, 102, 652-667. doi:10.1037/a0019643 
Kljajic, K., \& Gaudreau, P. (2018). Does it matter if students procrastinate more in some courses than in others? A multilevel perspective on procrastination and academic achievement. Learning and Instruction, 58, 193-200. doi:10.1016/j.learninstruc.2018.06.005

Krapohl, E., Rimfeld, K., Shakeshaft, N. G., Trzaskowski, M., McMillan, A., Pingault, J.-B., .. . Plomin, R. (2014). The high heritability of educational achievement reflects many genetically influenced traits, not just intelligence. Proceedings of the National Academy of Sciences, 111, 15273-15278. doi:10.1073/pnas.1408777111

Lane, S. R. (2018). Addressing the stressful first year in college: Could peer mentoring be a critical strategy? Journal of College Student Retention: Research, Theory \& Practice. doi:10.1177/1521025118773319

Larose, S., Ratelle, C. F., Guay, F., Senécal, C., \& Harvey, M. (2006). Trajectories of science self-efficacy beliefs during the college transition and academic and vocational adjustment in science and technology programs. Educational Research and Evaluation, 12, 373-393. doi:10.1080/13803610600765836

Lazarus, R. S., \& Folkman, S. (1984). Stress, appraisal, and coping. New York: Springer.

Lazowski, R. A., \& Hulleman, C. S. (2016). Motivation interventions in education: A metaanalytic review. Review of Educational Research, 86, 602-640. doi:10.3102/0034654315617832

Mabel, Z., \& Britton, T. A. (2018). Leaving late: Understanding the extent and predictors of college late departure. Social Science Research, 69, 34-51. doi:10.1016/j.ssresearch.2017.10.001

Mackenbach, J. P., Kulhánová, I., Bopp, M., Deboosere, P., Eikemo, T. A., Hoffmann, R., .. . Lundberg, O. (2015). Variations in the relation between education and cause-specific 
mortality in 19 european populations: A test of the "fundamental causes" theory of social inequalities in health. Social Science \& Medicine, 51-62.

doi:10.1016/j.socscimed.2014.05.021

Marsh, H. W., \& Craven, R. G. (2006). Reciprocal effects of self-concept and performance from a multidimensional perspective: Beyond seductive pleasure and unidimensional perspectives. Perspectives on Psychological Science, 1, 133-163. doi:10.1111/j.17456916.2006.00010.x

Marsh, H. W., Seaton, M., Trautwein, U., Ludtke, O., Hau, K. T., O'Mara, A. J., \& Craven, R. G. (2008). The big-fish-little-pond-effect stands up to critical scrutiny: Implications for theory, methodology, and future research Educational Psychology Review, 20, 319-350. doi:10.1007/s10648-008-9075-6

Marsh, H. W., Xu, M., \& Martin, A. J. (2012). Self-concept: A synergy of theory, method, and application. In K. R. Harris, S. Graham, T. Urdan, C. B. McCormick, G. M. Sinatra, \& J. Sweller (Eds.), APA educational psychology handbook, Vol 1: Theories, constructs, and critical issues (pp. 427-458). Washington, DC, US: American Psychological Association.

Martin, A. J. (2015). Growth approaches to academic development: Research into academic trajectories and growth assessment, goals, and mindsets. British Journal of Educational Psychology, 133-137. doi:10.1111/bjep.12071

Martin, A. J., \& Elliot, A. J. (2016). The role of personal best (PB) goal setting in students' academic achievement gains. Learning and Individual Differences, 45, 222-227. doi:10.1016/j.lindif.2015.12.014

Martin, A. J., Wilson, R., Liem, G. A. D., \& Ginns, P. (2013). Academic momentum at university/college: Exploring the roles of prior learning, life experience, and ongoing 
performance in academic achievement across time. Journal of Higher Education, 84, 640-674. doi:10.1353/jhe.2013.0029

Martin, R. C. (2015). Undergraduate superstars: What makes them stand out? Scholarship of Teaching and Learning in Psychology, 1, 107. doi:10.1037/st10000028

McAdams, D. P., \& Olson, B. D. (2010). Personality development: Continuity and change over the life course. Annual Review of Psychology, 61, 517-542. doi:10.1146/annurev.psych.093008.100507

McFarland, J., Hussar, B., Wang, X., Zhang, J., Wang, K., Rathbun, A., . . Bullock Mann, F. (2018). The Condition of Education 2018 (NCES 2018-144). U.S. Department of Education. Washington, DC: National Center for Education Statistics. Retrieved September 2019 from https://nces.ed.gov/pubsearch/pubsinfo.asp?pubid=2018144.

Mehl, M. R., \& Conner, T. S. (2012). Handbook of research methods for studying daily life. New York, NY: Guilford.

Mok, M. M. C., McInerney, D. M., Zhu, J., \& Or, A. (2014). Growth trajectories of mathematics achievement: Longitudinal tracking of student academic progress. British Journal of Educational Psychology, 85, 154-171. doi:10.1111/bjep.12060

Murayama, K., \& Elliot, A. J. (2011). Achievement motivation and memory: Achievement goals differentially influence immediate and delayed remember-know recognition memory. Personality and Social Psychology Bulletin, 37, 1339-1348. doi: $10.1177 / 0146167211410575$

Murayama, K., Pekrun, R., Lichtenfeld, S., \& vom Hofe, R. (2013). Predicting long-term growth in students' mathematics achievement: The unique contributions of motivation and cognitive strategies. Child Development, 84, 1475-1490. doi:10.1111/cdev.12036 
Muthén, B. O., \& Muthén, L. K. (2000). The development of heavy drinking and alcohol-related problems from ages 18 to 37 in a US national sample. Journal of Studies on Alcohol, 61, 290-300. doi:10.15288/jsa.2000.61.290

Nora, A., Barlow, E., \& Crisp, G. (2005). Student persistence and degree attainment beyond the first year in college: The need for research In A. Seidman (Ed.), College student retention: Formula for success (pp. 129-154). Westport, CT: American Council on Education

Oseguera, L., \& Rhee, B. S. (2009). The influence of institutional retention climates on student persistence to degree completion: A multilevel approach. Research in Higher Education, 50, 546-569. doi:10.1007/s11162-009-9134-y

Pan, W., Guo, S., Alikonis, C., \& Bai, H. (2008). Do intervention programs assist students to succeed in college?: A multilevel longitudinal study. College Student Journal, 42, 90-98.

Permzadian, V., \& Credé, M. (2015). Do first-year seminars improve college grades and retention? A quantitative review of their overall effectiveness and an examination of moderators of effectiveness. Review of Educational Research. doi:10.3102/0034654315584955

Richardson, M., Abraham, C., \& Bond, R. (2012). Psychological correlates of university students' academic performance: A systematic review and meta-analysis. Psychological Bulletin, 138, 353-387. doi:10.1037/a0026838

Robbins, S. B., Lauver, K., Le, H., Davis, D., Langley, R., \& Carlstrom, A. (2004). Do psychosocial and study skill factors predict college outcomes? A meta-analysis. Psychological Bulletin, 130, 261-288. doi:10.1037/0033-2909.130.2.261 
Robbins, S. B., Oh, I.-S., Le, H., \& Button, C. (2009). Intervention effects on college performance and retention as mediated by motivational, emotional, and social control factors: Integrated meta-analytic path analyses. Journal of Applied Psychology, 94, 1163 1184. doi:10.1037/a0015738

Roe, R. A. (2014). Time, performance and motivation. In A. J. Shipp \& Y. Fried (Eds.), Time and Work (Vol. 1, pp. 73-120). New York: Psychology Press.

Schaller, M. A. (2010). College sophomores: The journey into self. In M. S. Hunter, B. F. Tobolowsky, \& J. N. Gardner (Eds.), Helping sophomores succeed: Understanding and improving the second-year experience (pp. 66-79). New York: Jossey-Bass.

Schneider, M., \& Preckel, F. (2017). Variables associated with achievement in higher education: A systematic review of meta-analyses. Psychological Bulletin, 143, 565-600. doi:10.1037/bul0000098

Schreiner, L. A. (2010). Factors that contribute to sophomore success and satisfaction In M. S. Hunter, B. F. Tobolowsky, J. N. Gardner, S. E. Evenbeck, J. A. Pattengale, M. A. Schaller, \& L. A. Schreiner (Eds.), Helping sophomores succeed: Understanding and improving the second year experience (pp. 43-65). San Francisco, CA: Jossey-Bass.

Schreiner, L. A., \& Pattengale, J. (2000). Visible Solutions for Invisible Students: Helping Sophomores Succeed (Vol. Monograph Series No. 31). Columbia, SC: National Resource Center for the First-Year Experience and Students in Transition.

Shavelson, R. J., Zlatkin-Troitschanskaia, O., \& Mariño, J. P. (2018). International performance assessment of learning in higher education (iPAL): Research and development. In Z.-T. O., T. M., P. H., L. C., \& K. C. (Eds.), Assessment of Learning Outcomes in Higher Education (pp. 193-214): Springer. 
Silverman, A., \& Cohen, G. (2014). Fostering positive narratives: Social-psychological interventions to maximize motivation in the classroom and beyond. In S. A. Karabenick \& T. Urdan (Eds.), Advances in motivation and achievement (Vol. 18 Motivational Interventions, pp. 177-211). New York: Emerald.

Smith, W. C., Anderson, E., Salinas, D., Horvatek, R., \& Baker, D. P. (2015). A meta-analysis of education effects on chronic disease: The causal dynamics of the population education transition curve. Social Science \& Medicine, 29-40. doi:10.1016/j.socscimed.2014.10.027

Soderstrom, N. C., \& Bjork, R. A. (2015). Learning versus performance: An integrative review. Perspectives on Psychological Science, 10, 176-199. doi:10.1177/1745691615569000

Sterling, A. J. (2018). Student experiences in the second year: Advancing strategies for success beyond the first year of college. Strategic Enrollment Management Quarterly, 5, 136149. doi:10.1002/sem3.20113

Suarez-Orozco, C., Gaytan, F. X., Bang, H. J., Pakes, J., O'Connor, E., \& Rhodes, J. (2010). Academic trajectories of newcomer immigrant youth. Developmental Psychology, 46, 602-618. doi:10.1037/a0018201

Titus, M. A. (2004). An examination of the influence of institutional context on student persistence at 4-year colleges and universities: A multilevel approach. Research in Higher Education, 45, 673-699. doi:10.1023/B:RIHE.0000044227.17161.fa

Tobolowsky, B. F. (2008). Sophomores in transition: The forgotten year. New Directions for Higher Education, 144, 59-67. doi:10.1002/he.326

Tolar, T. D., Barth, A. E., Fletcher, J. M., Francis, D. J., \& Vaughn, S. (2014). Predicting reading outcomes with progress monitoring slopes among middle grade students. Learning and Individual Differences, 30, 46-57. doi:10.1016/j.lindif.2013.11.001 
van der Zanden, P. J. A. C., Denessen, E., Cillessen, A. H. N., \& Meijer, P. C. (2018). Domains and predictors of first-year student success: A systematic review. Educational Research Review, 23, 57-77. doi:10.1016/j.edurev.2018.01.001

Webb, O. J., \& Cotton, D. R. E. (2018). Deciphering the sophomore slump: changes to student perceptions during the undergraduate journey. Higher Education. doi:10.1007/s10734018-0268-8

Weiner, B. (2010). The Development of an attribution-based theory of motivation: A history of ideas. Educational Psychologist, 45, 28-36. doi:10.1080/00461520903433596

Westrick, P. A., Le, H., Robbins, S. B., Radunzel, J. M. R., \& Schmidt, F. L. (2015). College performance and retention: A meta-analysis of the predictive validities of ACT® scores, high school grades, and SES. Educational Assessment, 20, 23-45.

doi:10.1080/10627197.2015.997614

Wiese, B. S. (2007). Successful pursuit of personal goals and subjective well-being. In B. R. Little, K. Salmela-Aro, \& S. D. Phillips (Eds.), Personal project pursuit: Goals, action, and human flourishing (pp. 301-328). Mahwah, NJ: Lawrence Erlbaum.

Yeager, D. S., \& Dweck, C. S. (2012). Mindsets that promote resilience: When students believe that personal characteristics can be developed. Educational Psychologist, 47, 302-314. doi:10.1080/00461520.2012.722805

Yeager, D. S., \& Walton, G. M. (2011). Social-psychological interventions in education: They’re not magic. Review of Educational Research, 81, 267-301. doi:10.3102/0034654311405999

Yue, H., \& Fu, X. (2017). Rethinking graduation and time to degree: A fresh perspective. Research in Higher Education, 58, 184-213. doi:10.1007/s11162-016-9420-4 
Table 1

Results of Growth Models of Academic Achievement from High School, $1^{\text {st }}$ Semester, and $2^{\text {nd }}$ Semester of $1^{\text {st }}$ Year University Students

\begin{tabular}{|c|c|c|c|c|}
\hline & \multicolumn{2}{|c|}{ Linear and Quadratic Growth } & \multicolumn{2}{|c|}{$\underline{\text { Piecewise Growth }}$} \\
\hline & Estimate & S.E. & Estimate & S.E. \\
\hline \multicolumn{5}{|l|}{ Fixed Effect } \\
\hline Intercept & $7.569 * *$ & 0.022 & $7.569 * *$ & 0.022 \\
\hline Slope \#1 & $-2.527 * *$ & 0.042 & $-1.763 * *$ & 0.025 \\
\hline Slope \#2 & $0.764 * *$ & 0.018 & $-0.230 * *$ & 0.020 \\
\hline \multicolumn{5}{|l|}{ Covariance } \\
\hline Intercept with slope \#1 & $0.533 * *$ & 0.022 & $0.765^{*}$ & 0.042 \\
\hline \multicolumn{5}{|l|}{ Variance } \\
\hline Intercept & $1.232 * *$ & 0.041 & $1.091 * *$ & 0.044 \\
\hline Slope \#1 & $0.299 * *$ & 0.021 & $1.129 * *$ & 0.069 \\
\hline Slope \#2 ${ }^{\mathrm{a}}$ & 0.000 & 0.000 & 0.000 & 0.000 \\
\hline \multicolumn{5}{|l|}{ Residual variance } \\
\hline Equal across the three time & $0.945^{* *}$ & 0.023 & $0.862 * *$ & 0.024 \\
\hline Model fit & $\begin{array}{l}\chi^{2}=321.7 \\
\mathrm{CFI}=.93 \\
\mathrm{SRMR}= \\
\mathrm{BIC}=446\end{array}$ & $\begin{array}{l}2, p<.001 \\
=.904 \\
\mathrm{IC}=44559\end{array}$ & $\begin{array}{l}\chi^{2}=63.88 \\
.001 ; \mathrm{CFI} \\
.981, \mathrm{SRN} \\
=44252,\end{array}$ & $\begin{array}{l}2, p< \\
8, \mathrm{TLI}= \\
.056, \mathrm{AIC} \\
=44296\end{array}$ \\
\hline
\end{tabular}

Note. $\mathrm{N}=4212 .{ }^{*} p<.01$. In both model, the intercept is high school GPA. In the linear and quadratic model, slope \#1 = linear, slope \#2 = quadratic. In the piecewise growth, slope \#1 = change between high school and $1^{\text {st }}$ semester, slope $\# 2$ = change between $1^{\text {st }}$ and $2^{\text {nd }}$ semester. ${ }^{\text {a }}$ Fixed at zero to ensure model identification but freely estimated and statistically significant $(0.201, S . E .=0.075, p<.05)$ in complementary analyses reported in the supplementary file. 
Table 2

Results of Growth Models of Academic Achievement from High School, $1^{\text {st }}$ Year, and $2^{\text {nd }}$ Year of University Students Returning for the $2^{\text {nd }}$ Year

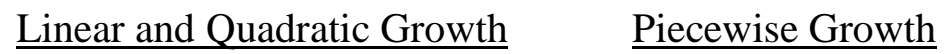

Estimate S.E. Estimate S.E.

Fixed Effect

Intercept

$7.672 * *$

0.023

$7.672 * *$

0.023

Slope \#1

$-2.534 * *$

0.039

$-1.669 * *$

0.023

Slope \#2

$0.865 * *$

0.018

$0.062 * *$

0.021

Covariance

Intercept with slope \#1

$0.246 * *$

0.022

$0.520 * *$

0.041

Variance

Intercept

$1.314 * *$

0.042

$1.082 * *$

0.046

Slope \#1

$0.287 * *$

0.020

$0.663 * *$

0.056

Slope \#2 ${ }^{\mathrm{a}}$

0.000

0.000

0.000

0.000

Residual variance

Equal across the three time

Model fit

$$
\begin{array}{ll}
\chi^{2}=125.04, d f=2, p<.001 ; & \chi^{2}=141.25, d f=2, p< \\
\mathrm{CFI}=.967, \mathrm{TLI}=.951, & .001 ; \mathrm{CFI}=.963, \mathrm{TLI}= \\
\mathrm{SRMR}=.132, \mathrm{AIC}=59225, & .944, \mathrm{SRMR}=.082, \mathrm{AIC}= \\
\mathrm{BIC}=59429 & 59227, \mathrm{BIC}=59431
\end{array}
$$

Note. $N=3600 .{ }^{*} p<.01$. In both model, the intercept is high school GPA. In the linear and quadratic model, slope \#1 = linear, slope \#2 = quadratic. In the piecewise growth, slope \#1 = change between high school and $1^{\text {st }}$ year, slope $\# 2=$ change between $1^{\text {st }}$ and $2^{\text {nd }}$ year. ${ }^{\text {a }}$ Fixed at zero to ensure model identification but freely estimated and statistically significant $(0.353, S . E$. $=$ $0.066, p<.05)$ in complementary analyses reported in the supplementary file. 
Table 3

Results of Growth Models of Academic Achievement across High School and Four Years at the University for Students Returning for the $3^{\text {rd }}$ Year

\begin{tabular}{|c|c|c|c|c|}
\hline & \multicolumn{2}{|c|}{ Linear and Quadratic Growth } & \multicolumn{2}{|c|}{$\underline{\text { Piecewise Growth }}$} \\
\hline & Estimate & S.E. & Estimate & S.E. \\
\hline \multicolumn{5}{|l|}{ Fixed Effect } \\
\hline Intercept & $7.548 * *$ & 0.024 & $7.738 * *$ & 0.024 \\
\hline Slope \#1 & $-1.235 * *$ & 0.021 & $-1.604 * *$ & 0.023 \\
\hline Slope \#2 & $0.267 * *$ & 0.005 & $0.182 * *$ & 0.010 \\
\hline \multicolumn{5}{|l|}{ Covariance } \\
\hline Intercept with slope \#1 & $0.346 * *$ & 0.033 & $0.270 * *$ & 0.038 \\
\hline Intercept with slope \#2 & $-0.083 * *$ & 0.007 & $-0.071 * *$ & 0.013 \\
\hline Slope \#1 with slope \#2 & $-0.037 * *$ & 0.010 & $-0.047 * *$ & 0.015 \\
\hline \multicolumn{5}{|l|}{ Variance } \\
\hline Intercept & $1.120 * *$ & 0.045 & $1.180 * *$ & 0.044 \\
\hline Slope \#1 & $0.246^{* *}$ & 0.043 & $0.622 * *$ & 0.052 \\
\hline Slope \#2 & $0.009 * *$ & 0.002 & $0.169 * *$ & 0.012 \\
\hline \multicolumn{5}{|l|}{ Residual variance } \\
\hline Equal across the five time & $0.851 * *$ & 0.021 & $0.642 * *$ & 0.020 \\
\hline Model fit & $\begin{array}{l}\chi^{2}=1197 . \\
.001 ; C F I \\
\text { SRMR }= \\
\text { BIC }=703\end{array}$ & $\begin{array}{l}=10, p< \\
\text { TLI }=.815 \\
\mathrm{IC}=70088\end{array}$ & \multicolumn{2}{|c|}{$\begin{array}{l}\chi^{2}=90.91, d f=10, p< \\
.001 ; \mathrm{CFI}=.987, \mathrm{TLI}= \\
.987, \mathrm{SRMR}=.042, \mathrm{AIC}= \\
68603, \mathrm{BIC}=68869\end{array}$} \\
\hline
\end{tabular}

Note. $N=3136 . * * p<.01$. In both model, the intercept is high school GPA. In the linear and quadratic model, slope \#1 = linear, slope \#2 = quadratic. In the piecewise growth, slope \#1 = change between high school and $1^{\text {st }}$ year, slope $\# 2=$ change in the $2^{\text {nd }}, 3^{\text {rd }}$, and $4^{\text {th }}$ year. 


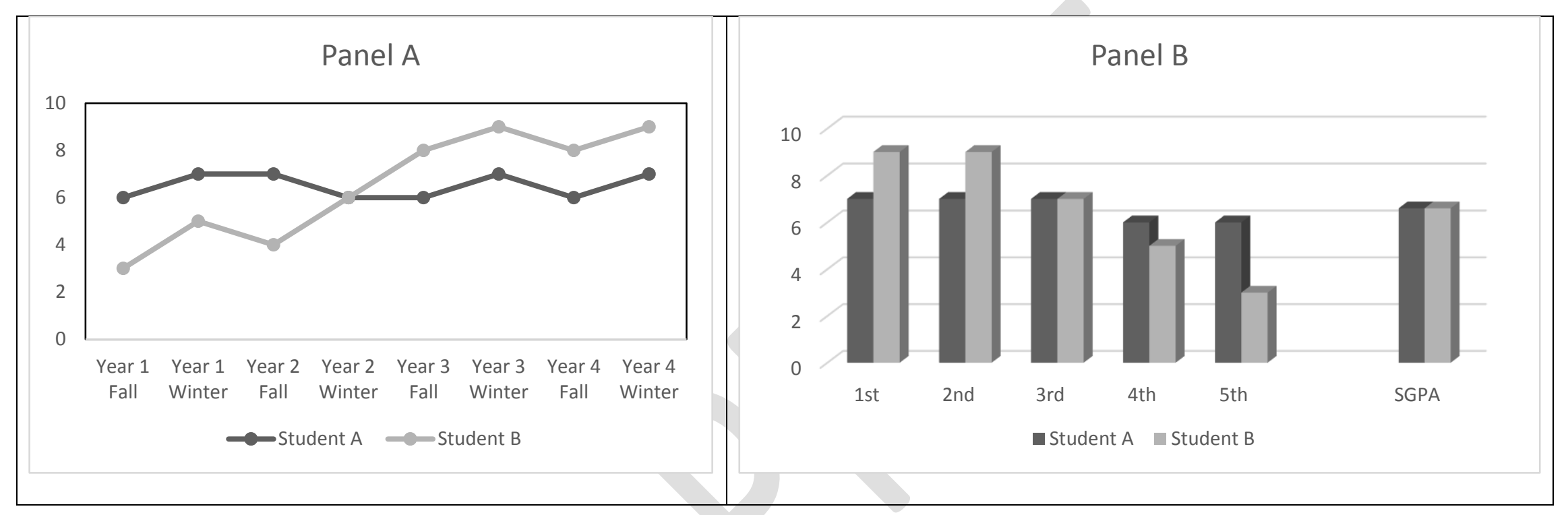

Figure 1. Panel A: Yearly grade point average of two prototypical students graduating with the same cumulative grade point average. Panel B: Grades in the five courses of two prototypical students finishing a semester with the same semester grade point average (SGPA) 


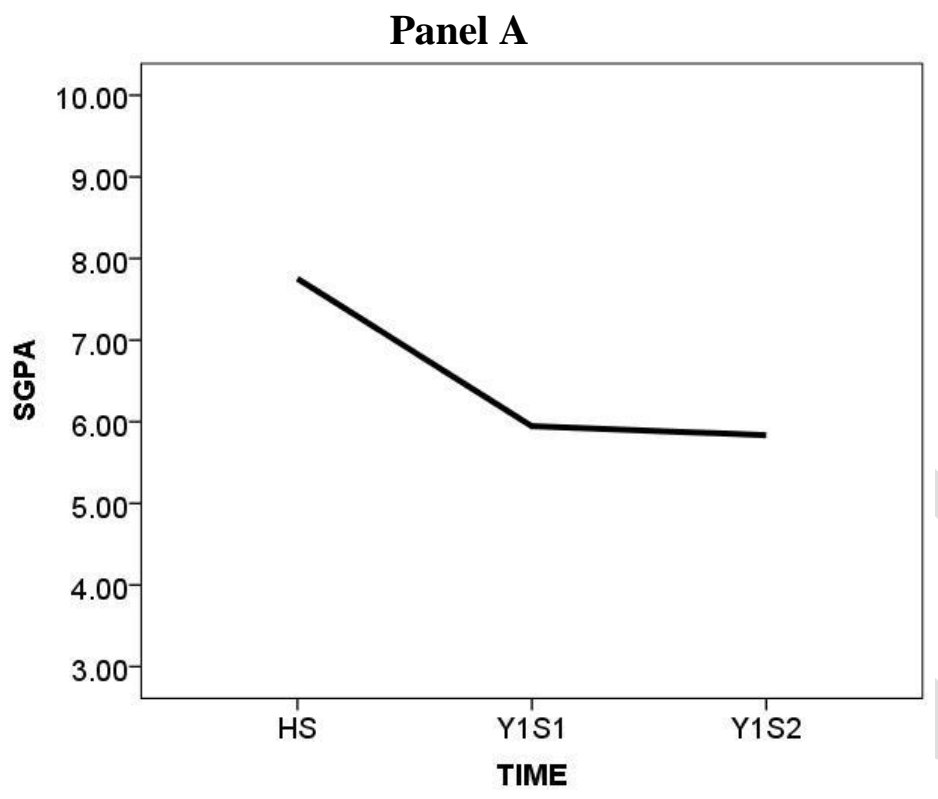

Panel B

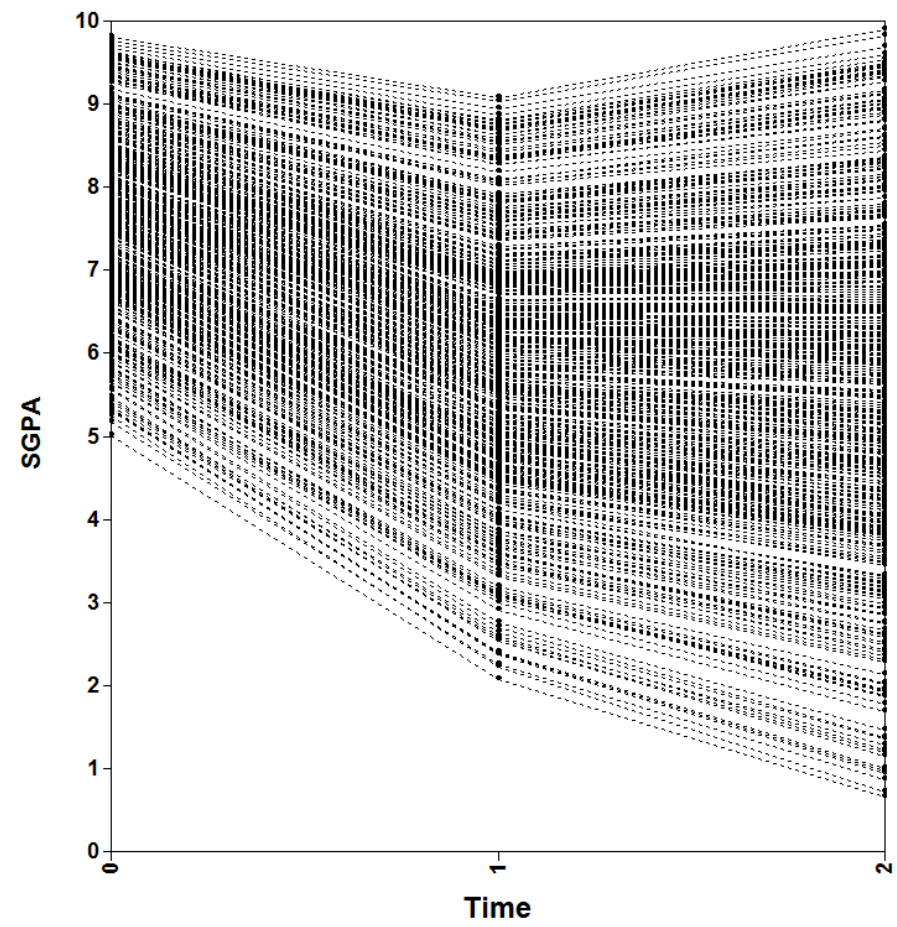

Figure 2. Panel A: Estimated academic achievement trajectory from high school (HS), $1^{\text {st }}$ semester (Y1S1), and $2^{\text {nd }}$ semester (Y1S2) of $1^{\text {st }}$ Year University Students. Panel B: Estimated individual academic achievement trajectory of 500 randomly selected students. SGPA = Semester Grade Point Average. $N=4212$. 


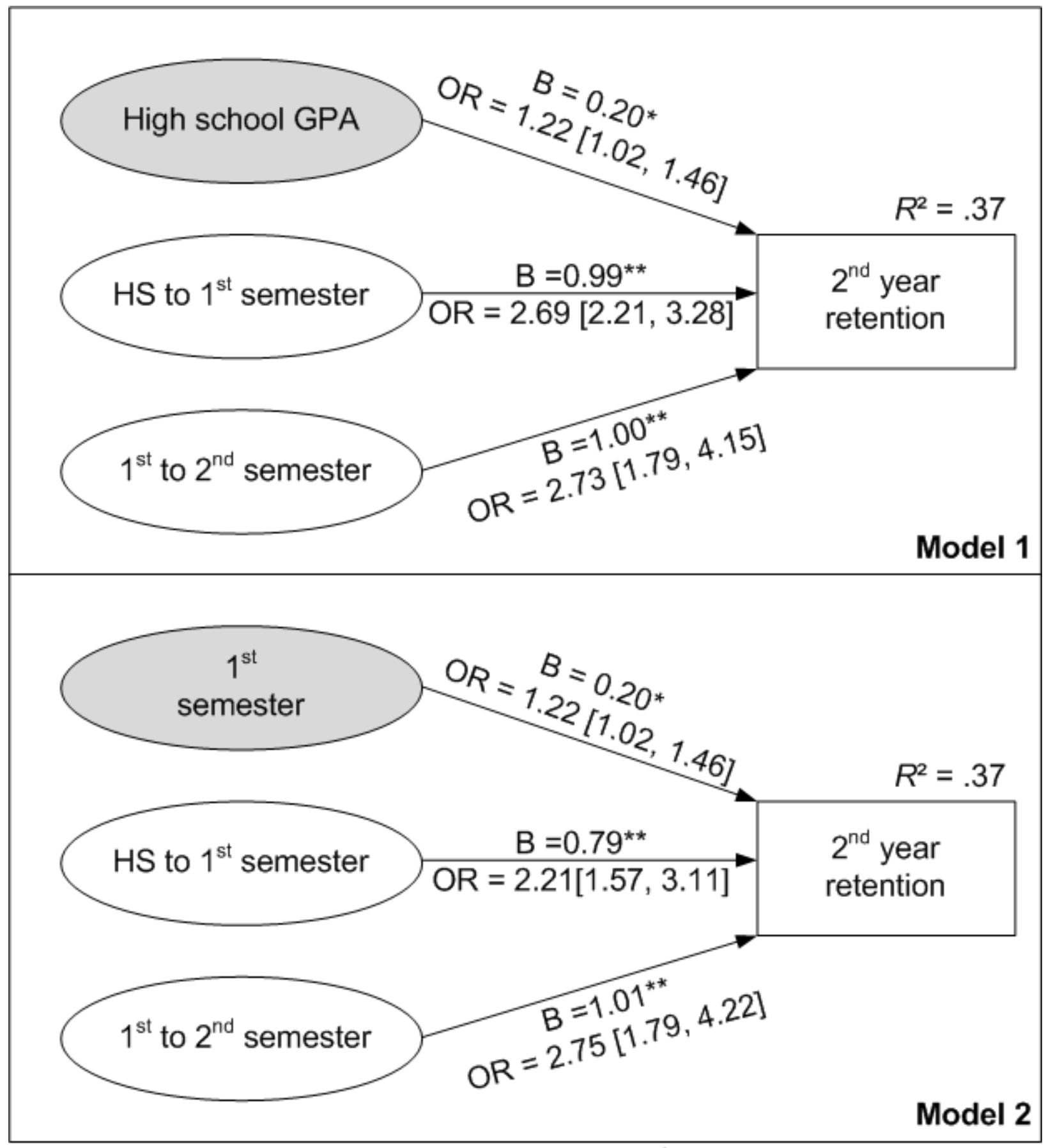

Figure 3. Changes in academic achievement predict $2^{\text {nd }}$ year retention after controlling for admission GPA (model 1) and $1^{\text {st }}$ semester GPA (model 2). Control variables are in grey. Parameters are unstandardized. $\mathrm{OR}=$ Odds ratio. $N=4212.2^{\text {nd }}$ year retention equals $85.5 \%$. ${ }^{* *} p<.01 .{ }^{*} p<.05$. 


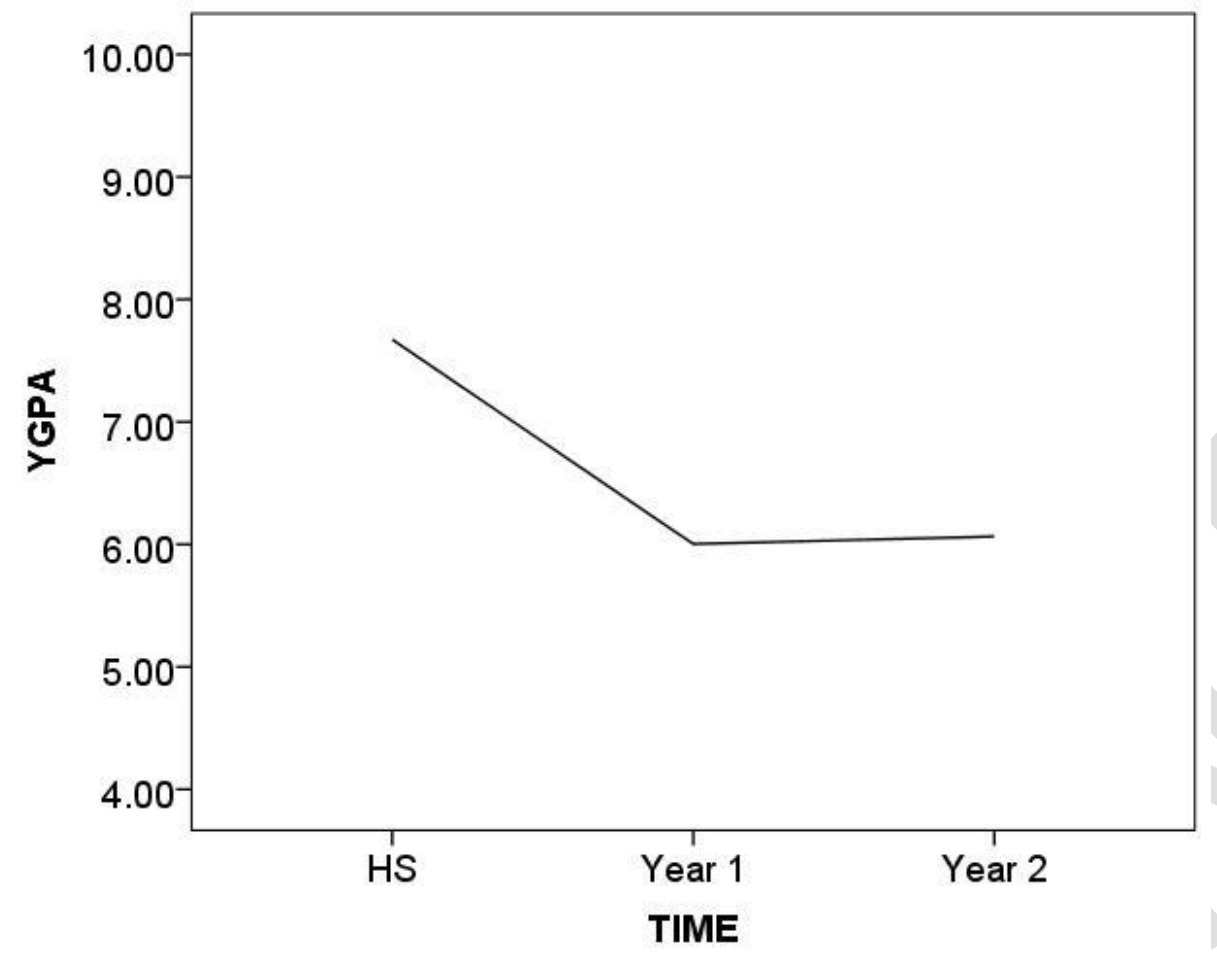

Figure 4. Estimated achievement trajectory from high school (HS), $1^{\text {st }}$ year, and $2^{\text {nd }}$ year of university students returning for the $2^{\text {nd }}$ year. YGPA $=$ Yearly Grade Point Average. $N=3600$. 


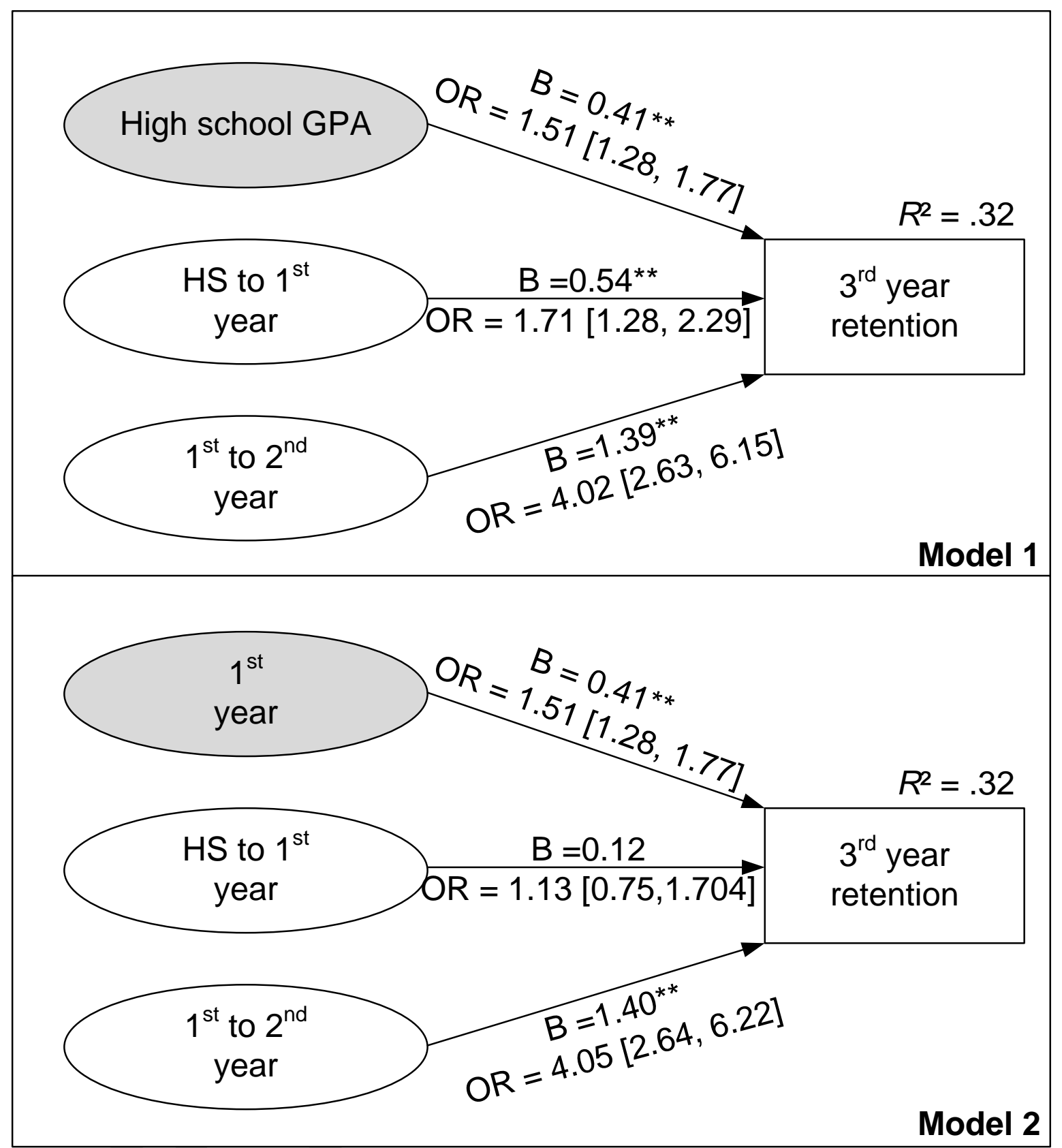

Figure 5. Changes in academic achievement predict $3^{\text {rd }}$ year retention after controlling for admission GPA (model 1 ) and $1^{\text {st }}$ year GPA (model 2). Control variables are in grey. Parameters are unstandardized. $\mathrm{OR}=$ Odds ratio. $N=3600$ returning in $2^{\text {nd }}$ year, of which $84.9 \%$ returned in 3 rd year. ${ }^{* *} p<.01 .{ }^{*} p<.05$. 


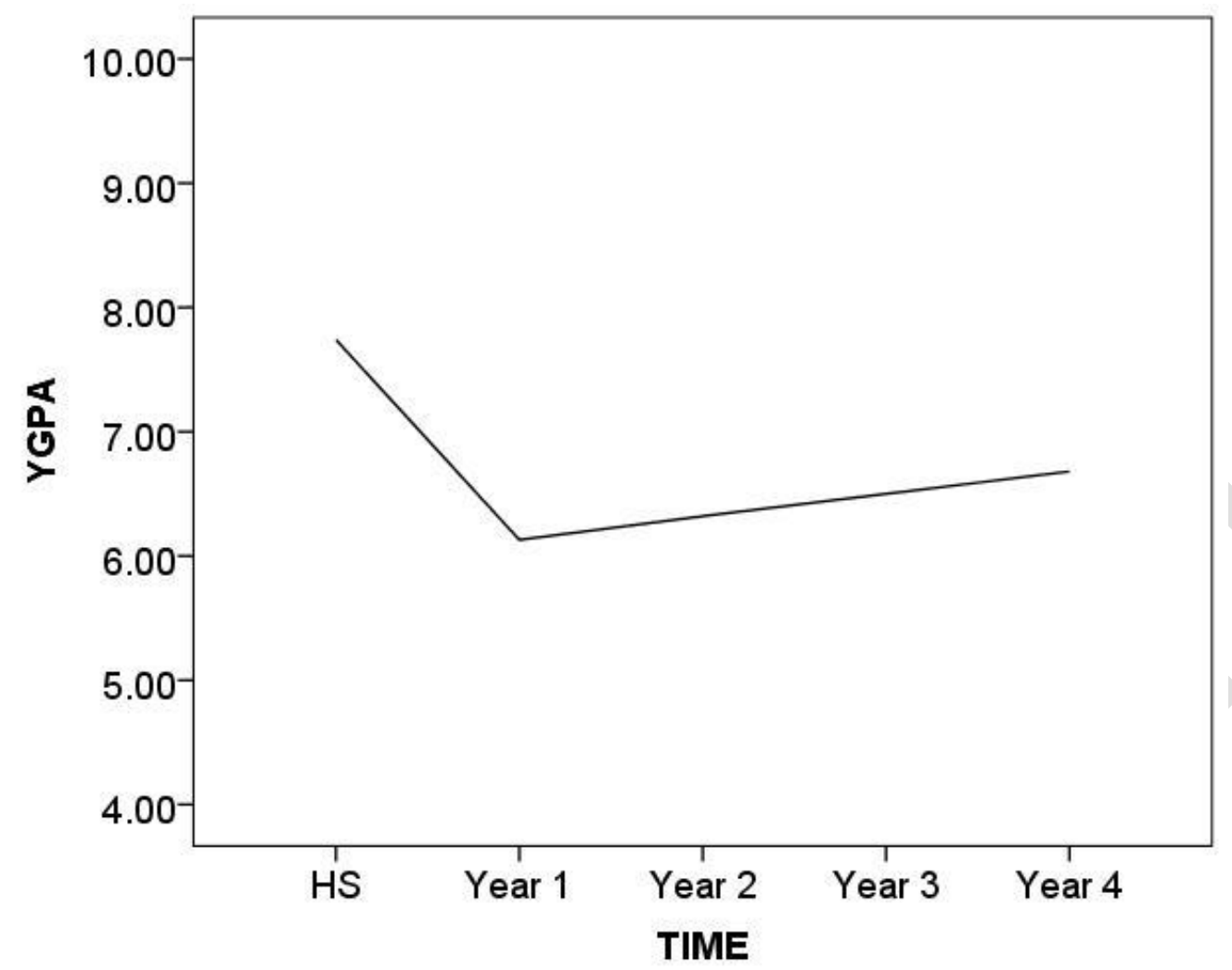

Figure 6. Estimated achievement trajectory across high school and four years at the university for students returning for the $3^{\text {rd }}$ year. YGPA $=$ Yearly Grade Point Average. $N=3136$. 


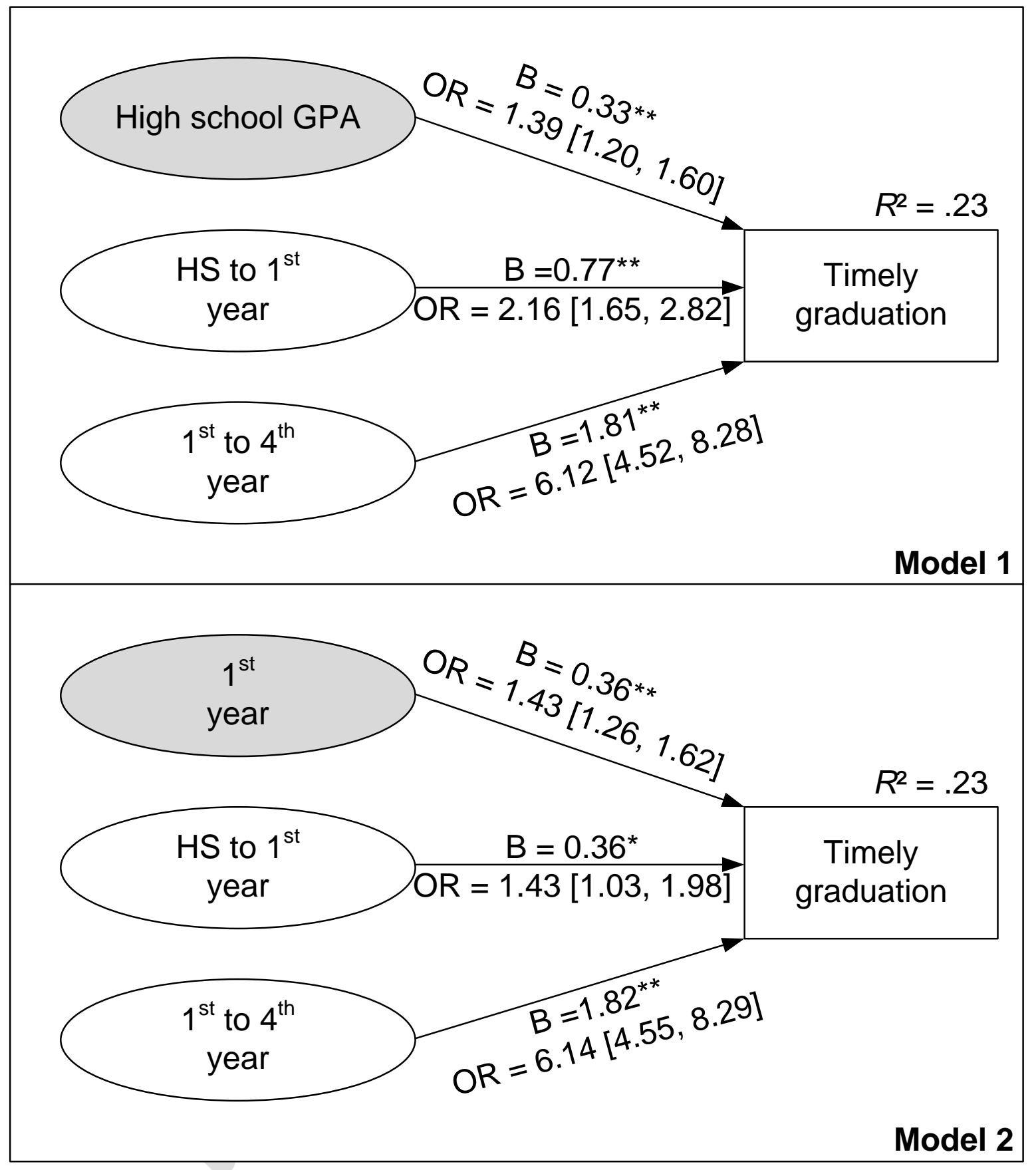

Figure 7. Changes in academic achievement predict graduation after the $4^{\text {th }}$ year while controlling for admission GPA (model 1 ) and $1^{\text {st }}$ year GPA (model 2). Control variables are in grey. Parameters are unstandardized. OR $=$ Odds ratio. $N=3136$ returning in $3^{\text {rd }}$ year, of which $47.4 \%$ graduated in four years. ${ }^{* *} p<.01 .{ }^{*} p<.05$. 